\begin{tabular}{|l|c|c|c|c|}
\hline $\begin{array}{l}\text { Cuadernos de Investigación Geográfica } \\
\text { Geographical Research Letters }\end{array}$ & 2019 & N $^{\circ} 45(1)$ & pp. 333-366 & eISSN 1697-9540 \\
\hline
\end{tabular}

\title{
ECOSYSTEM SERVICES PROVISION BY GULLY CONTROL. A REVIEW
}

\author{
A. ROMERO-DÍAZ ${ }^{1 *}$, E. DÍAZ-PEREIRA ${ }^{2}$, J. DE VENTE $^{2}$ \\ ${ }^{1}$ Departamento de Geografía, Universidad de Murcia, Campus de La Merced, 30001 Murcia, Spain. \\ ${ }^{2}$ Grupo de Conservación de Suelo y Agua, CEBAS, Consejo Superior de Investigaciones Científicas \\ (CSIC), Campus de Espinardo, 30100 Murcia, Spain.
}

\begin{abstract}
Gully erosion causes severe damage to crops and infrastructures and affects the provision of ecosystem services worldwide. To assess the potential of gully control measures to protect ecosystem services and assess the conditions required for their large-scale implementation, this paper critically evaluates a range of gully control measures documented in the World Overview of Conservation Approaches and Technologies (WOCAT). Environmental and socio-economic impacts of technologies are assessed, as well as the implications for ecosystem services, costs and benefits of implementation, and stakeholder's perception. It is demonstrated how gully control measures provide notable on-site and off-site benefits for socio-economic, cultural, ecological, and production goals, and to protect crucial ecosystem services. Control measures particularly contribute to soil and water conservation and to regulating ecosystem services by controlling soil erosion, water cycling, and natural hazards. Most effective control measures consist of combined vegetative and structural measures and of catchment wide interventions. While implementation of gully control can initially be expensive, on the long term, the cost-benefit ratio is usually positive. Moreover, the results emphasize the importance of evaluating control measures considering monetary aspects and all ecosystem services they provide. Nevertheless, individual farmers can often not afford the implementation and maintenance costs due to barriers for implementation and therefore require sustained institutional support.
\end{abstract}

\section{Servicios ecosistémicos proporcionados por el control de cárcavas. Una revisión}

RESUMEN. La erosión de cárcavas causa graves daños a los cultivos e infraestructuras y afecta la prestación de servicios ecosistémicos en todo el mundo. Para evaluar el potencial que las medidas de control de cárcavas tienen en estos y evaluar las condiciones requeridas para su implementación a gran escala, en este trabajo se analizan críticamente una serie de medidas de control de cárcavas documentadas en World Overview of Conservation Approaches and Technologies, WOCAT. Se evalúan los impactos ambientales y socioeconómicos de las diferentes tecnologías, así como sus implicaciones en los servicios ecosistémicos, los costos y beneficios de implementación y la percepción de las partes interesadas. Se constata 
cómo las medidas de control de cárcavas proporcionan notables beneficios "on site" y "off site" desde un punto de vista socioeconómico, cultural, ecológico y de producción, al tiempo que protegen servicios cruciales de los ecosistemas. Las medidas de control contribuyen particularmente a la conservación del suelo y el agua y a los servicios ecosistémicos de regulación a través del control de la erosión del suelo, el ciclo del agua y los riesgos naturales. Las medidas de control más eficaces consisten en la combinación de medidas vegetativas y estructurales y es importante la intervención en toda la cuenca hidrográfica. Si bien la implementación del control de cárcavas puede ser inicialmente costosa, a largo plazo, la relación costo-beneficio es generalmente positiva. Además, los resultados enfatizan la importancia de evaluar las medidas de control considerando tanto los aspectos económicos, como todos los servicios ecosistémicos que proporcionan. Sin embargo, a menudo los agricultores, de manera individual, no pueden sufragar los costos de implementación y mantenimiento, por lo que requieren un apoyo institucional sostenido.

Key words: ecosystem services, gully control, soil and water conservation, sustainable land management, WOCAT.

Palabras clave: servicios ecosistémicos, control de cárcavas, conservación de suelos y agua, gestión sostenible de la tierra, WOCAT.

Received: 15 February 2018

Accepted: 13 July 2018

*Corresponding author: Asunción Romero-Díaz, Departamento de Geografía, Campus de La Merced, Universidad de Murcia, 30001 Murcia, Spain. E-mail address: arodi@um.es

\section{Introduction}

Gully erosion is one of the principal processes leading to land degradation in different environments (Nadal Romero and Regüés, 2010; Gallart et al., 2013; Vanmaercke et al., 2016) and at different spatial and temporal scales, causing considerable soil losses and exporting large amounts of sediment and important damage to infrastructure (Poesen et al., 2003; Valentin et al., 2005)

According to Ionita et al. (2015), gullies constitute one of the most important forms of water erosion and represent a significant environmental threat worldwide, affecting multiple functions of soil and land. Gully erosion is a significant driver of land degradation globally as is illustrated by the magnitude of soil erosion rates by gully erosion and the numerous countries that are severely affected (Pathak et al., 2005; Brown, 1981; Castillo and Gómez, 2016).

A gully, as defined by the Soil Conservation Society of America (1982), is "a channel or miniature valley cut by concentrated runoff through which water commonly flows only during and immediately after heavy rains or during the melting of snow; it may be dendritic or branching or linear, rather long, narrow, and of uniform width". Kirkby and Bracken (2009) stated that "a gully is normally defined as deep channel on a hillside, generally cut by running water, and often not containing a perennial flow". 
The distinction between rills and gully is usually done arbitrarily according to size. Another aspect to consider is the difference between ephemeral and permanent gullies. Ephemeral gullies (small in size) can be eliminated by tillage; by contrast, permanent gullies represent structures that cannot be eliminated by tillage (Gómez Gutiérrez et al., 2001). A particular type of gully is associated with margins or crop terraces; known as bank gullies (Poesen and Hooke, 1997) that are usually formed in the topographic discontinuities caused by terraces.

Gully formation is linked to natural factors such as erodible soils, unstable slopes, or intense precipitation. Desmet et al. (1999) and Vandekerckhove et al. (2000) emphasized the importance that the slope and the contributing area have in the formation of gullies given their importance for the generation of runoff depth. Recently, demographic pressure and certain human activities - such as deforestation, inadequate land use, certain agricultural practices, or abandonment of agricultural land (Romero Díaz et al., 2016) - have increased soil degradation and, in particular, the risk of erosion by gullies. Many studies suggested that under climate change scenarios, erosion rates, and in particular gully erosion, may increase (Nearing et al., 2004; Zhang et al., 2012), due to an increase in the frequency of extreme weather events (Sun et al., 2007; Sillman et al., 2013). Vanmaercke et al. (2016) also suggested that specifically gully erosion will become more intense and widespread worldwide in the following decades due to climate change.

Poesen et al . (2002) indicated that gully erosion contributes between 50\% and $80 \%$ to total sediment yield on dryland agricultural land, even though the gullies occupy less than $5 \%$ of the watershed area. Gullies produce both on-site and off-site effects. Table 1 shows some of the main effects reported by different authors.

Table 1. Overview of "on site" and "off site" effects of gully erosion.

\begin{tabular}{|c|c|}
\hline “On Site" effects & Reference \\
\hline Notable losses of soil & $\begin{array}{l}\text { Poesen } \text { et al., 2002, 2006; Gómez et al., 2003; Martínez Casas- } \\
\text { novas et al., } 2003\end{array}$ \\
\hline Source of sediments & $\begin{array}{l}\text { Poesen } \text { et al., 1996, 2003; Martínez-Casasnovas et al., 2003; } \\
\text { Shellberg et al., 2013; Martín-Moreno et al., 2014. }\end{array}$ \\
\hline Loss of agricultural land & Avni, 2005; Mansour Jahantigh and Pessarakli, 2011. \\
\hline Decline in crop yields & $\begin{array}{l}\text { Poesen } \text { et al., 2003; Nyssen } \text { et al., 2004; Den Biggelaar } \text { et al., } \\
\text { 2004; Bakker } \text { et al., 2004, 2007; Ionita, 2011; Marzolff } \text { et al., } \\
\text { 2011; Ionita } \text { et al., 2015; Ollobarren } \text { et al., 2016; Li } \text { et al., } 2016 .\end{array}$ \\
\hline $\begin{array}{l}\text { Expansion of the drainage net- } \\
\text { work and development of gullies }\end{array}$ & $\begin{array}{l}\text { Nyssen et al., 2004; Palacio Prieto and López Blanco, 1994; } \\
\text { Vandekerckhove et al., 2001; Ries and Marzolff, } 2003\end{array}$ \\
\hline Rise in agricultural costs & Valentin et al., 2005; Santos Telles et al., 2011; Panagos et al., 2018 \\
\hline “Off site" effects & Reference \\
\hline $\begin{array}{l}\text { Silting-up of reservoirs and } \\
\text { loss of functionality }\end{array}$ & $\begin{array}{l}\text { Poesen } \text { et al., 2002; de Vente } \text { et al., 2005; Haregeweyn } \text { et al., } \\
\text { 2003; Valentin et al., 2005; Haregeweyn et al., 2008 }\end{array}$ \\
\hline Increment in floods & $\begin{array}{l}\text { Poesen and Hooke, 1997; Martineli Costa and Prado Bacellar, } \\
\text { 2007; Obi Lawrence, } 2017 .\end{array}$ \\
\hline $\begin{array}{l}\text { Contamination of soils and } \\
\text { surface waters }\end{array}$ & Toy et al., 2002; Gómez et al., 2017; Issaka and Ashraf, 2017. \\
\hline
\end{tabular}

Source: Own elaboration 
Due to the important on-site and off-site effects of erosion processes in gullies, their control is very necessary. Poesen (2018) states that actually there is a need for more research on innovative techniques and strategies to prevent soil erosion or reduce erosion rates in general. There are many different techniques, materials, and strategies, depending on the specific problems to be solved, the environmental characteristics, and the resources and labor available (Milton, 1971). For decades, structural measures, such as the construction of check dams (Heede and Mufich, 1974; Schouten and Rang, 1984) as well as vegetative measures, consisting of the establishment of different types of vegetation with the aim of stabilizing the soil or impeding gully development (Baade et al., 1993) have been used for gully control. Structural-vegetative measures combine both types of measure (Okagbue and Uma, 1987; Sheng and Liao, 1997; Weinhold, 2007).

Gully erosion has received important attention within the scientific community over past decades (Poesen and Valentin, 2003; Nadal Romero et al., 2010, 2013; Ionita et al., 2015; Vanmaercke et al., 2016; Zglobicki et al., 2017; Poesen, 2018) but in spite of this, it only represents $10 \%$ of the research on soil erosion (Castillo and Gómez, 2016). This is a very small percentage considering that gullies are the most important form of soil degradation in agricultural areas (Castillo and Gómez, 2016). According to Liggitt and Fincham (1989), gully erosion is the neglected dimension in soil conservation research. Poesen et al. (2003) considered that most research on water erosion processes focused on sheet and rill erosion processes. Relatively few studies have focused on gully erosion and even scarcer are the studies on the control of gully erosion. Poesen (2011) mentioned many issues still to be resolved in the study of gullies, among which he cites the need to "determine effective measures for the prevention and control of gullies", which is the central theme of our research. According to a review by Castillo and Gómez (2016), gully control was investigated in only $4.2 \%$ of the publications about gullies, despite it being a problem of fundamental interest.

A full understanding of the importance of gully control measures requires assessment of their contribution to ecosystem services. Ecosystem Services (ES) as "the benefits that we human beings get, directly or indirectly, from ecosystems" and can be classified in four groups: provisioning (i.e. wood, water), regulating (i.e. flood and pest control), cultural (i.e. spiritual, recreation), and supporting (i.e. nutrient cycling) services (MA 2005). The benefits can be tangible or intangible and are derived from nature for human benefit. These benefits can often be valued economically -in order to equate them with economic activities that involve changes in land use- and thus provide additional arguments for ecosystem conservation and management (Camacho Valdez and Ruiz Luna, 2012). An important application of the ES concept is that it allows the allocation of value to the provision of goods and services that would otherwise not be considered by political and economic decision-making bodies (Ferrer et al., 2012) and facilitates its fair comparison with costs of prevention or restoration measures. ES can be considered either as benefits (Costanza, 2008) or broader as contributions to human well-being (Potschin and Haines-Young, 2011). 
The general objective of our study was to evaluate the environmental and socioeconomic (positive and negative) impacts and the ecosystem services provided by gully control measures worldwide based on review and assessment of gully control measures included in the WOCAT (World Overview of Conservation Approaches and Technologies) database and additional scientific literature, thereby specifically combining local and scientific knowledge. The evaluation includes aspects like: the costbenefit ratio of the implementation of gully control measures, their effectivity in different contexts, and the opinions that farmers and experts have of the existing land degradation caused by gullies and the need to reverse it.

\section{Methods}

The World Overview of Conservation Approaches and Technologies (WOCAT) is a global network that supports the processes of innovation and decision making in Sustainable Land Management (SLM). The overall objective of the network is to unite efforts in knowledge management and decision support, in order to scale up SLM among stakeholders, including national governmental and non-governmental institutions and international and regional (WOCAT, 2016). WOCAT provides universal knowledge of a wide range of experiments and techniques developed in the field, together with the advantages and disadvantages of their application, from which finally impacts on ecosystem services (ES) can be extracted. It also provides a standard method for documenting, assessing, comparing and analysing the application of technologies and approaches to the existing natural and human environment and is based on the knowledge and assessment of both land users and experts (Mekdaschi Studer and Liniger, 2007). The WOCAT database currently contains 600 technologies developed in 50 countries and is recommended as a reference for the documentation of SLM techniques by the United Nations Convention to Combat Desertification (UNCCD).

For the present study, all entries in the WOCAT database related to the control of gullies in all climates and continents were evaluated. The typologies of the different technologies, their environmental characteristics, the cost-benefit ratio of their implementation and maintenance, and the positive and negative impacts of the different technologies were analysed. Based on this assessment the benefits from gully control for ecosystem services been determined.

The classifications used for assessment of the advantages, disadvantages, impacts and categories (high, medium and low) are those that are listed in the World Overview of Conservation Approaches and Technologies Questionnaire on Sustainable Land Management (SLM) (WOCAT, 2016).

We analysed 26 technologies documented in detail in WOCAT, of which 58\% correspond to Africa (Ethiopia, Morocco, South Africa, Senegal, and Tanzania); $31 \%$ to Asia (China, India, Nepal, and Tajikistan); and $11 \%$ to America (Bolivia and Nicaragua). The largest number of examples in the database originated from Ethiopia, which also reflects the numerous scientific studies related to the control of gullies (e.g. Nyssen 
et al., 2004; Moges and Holden, 2008; Yitbarek et al., 2012; Haile and Fetene, 2012; Frankl et al., 2013, 2014; Ehrensperger et al., 2015; Addis et al., 2015; Haregeweyn et al., 2015). In addition to the analysis of the WOCAT database, which only includes measures applied in Africa, Asia and America, a review of studies involving analyses of the measures used for gully control in other countries appears further on in Table 4 and was used further in the discussion.

\subsection{General and environmental characteristics of the technologies applied}

From a climatic point of view, 21 of the gully control technologies documented in the WOCAT database originated from semiarid climates, three from subhumid climates, one from a semiarid-subhumid climate, and one from a humid climate (Table 2). Nineteen percent of the evaluated control measures were implemented in areas with precipitation below $500 \mathrm{~mm} ; 42 \%$ between 500 and $750 \mathrm{~mm}$, and $39 \%$ more than $750 \mathrm{~mm}$. Of the territories involved, $60 \%$ lies at $500-2000 \mathrm{~m}$ altitude, with the most frequent slopes classified as moderate and steep (each representing 23\%), followed by gentle and hilly slopes with $19 \%$ each. The forms of relief are diverse although hill slopes predominate representing $31 \%$ of the total. Plateau, mountain slopes, and footslopes represent $15 \%$ each (Table 2).

The area in which the technologies are applied is generally small, since they are specific actions on specific sites. In $61 \%$ of the cases the area involved was between 0.1 and $1 \mathrm{~km}^{2}$, in $19 \%$ between 1 and $10 \mathrm{~km}^{2}$, and in $12 \%$ between 10 and $100 \mathrm{~km}^{2}$. The type of degradation that gully control techniques aim to mitigate is exclusively due to water erosion. The causes of degradation indicated are usually a combination of natural and man-made causes. The main technical functions that is intended to be achieved are the control of the concentrated runoff (in 65\% of the cases) or the combination of several functions -among which increased infiltration, storage of water, and sediment retention. The measures applied have been mainly structural $(46 \%)$, vegetative $(11.5 \%)$, and combinations of both $(38.5 \%)$. Regarding the type of intervention, most have been measures for rehabilitation or combinations of rehabilitation, prevention, mitigation, and reduction of land degradation (Table 2). Where gully control measures are implemented, the soil use was mainly mixed land $(46 \%)$ and cropland $(31 \%)$. The applied technologies have an external origin in $61.5 \%$ of the cases, while $38.5 \%$ have their origin in local knowledge (Table 2). The soils where the evaluated control measures were implemented are generally characterized by an average depth between 20 and $80 \mathrm{~cm}$ (in $46 \%$ of cases); are of medium texture (58\% of cases); with low fertility (54\% of cases); and with a low percentage of organic matter in their upper layers ( $<1 \%$ in $65 \%$ of cases) (Table 2$)$. 


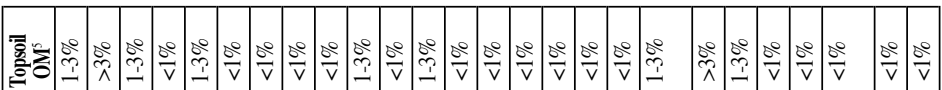

$\stackrel{2}{\check{2}}$

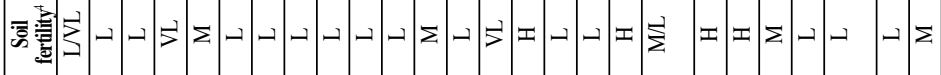

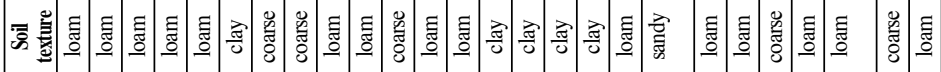

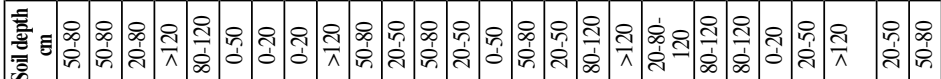

इ

$\frac{2}{2}$

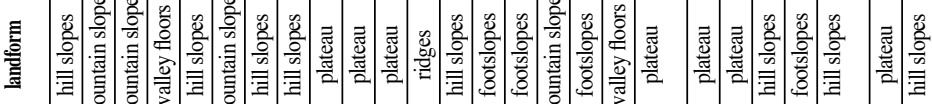

y

10

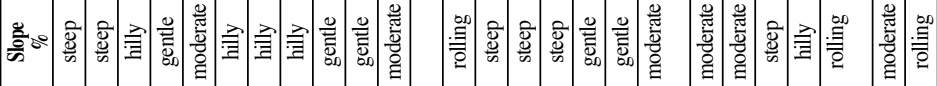

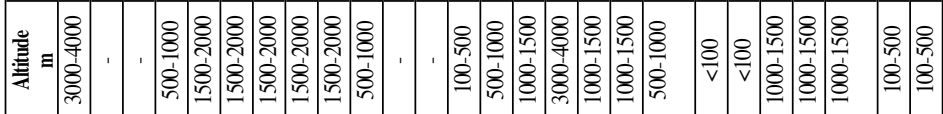

善

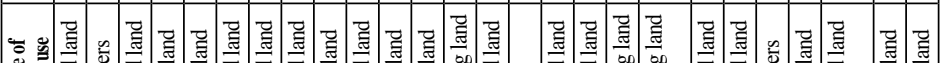

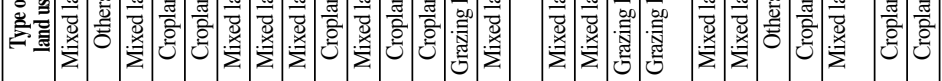

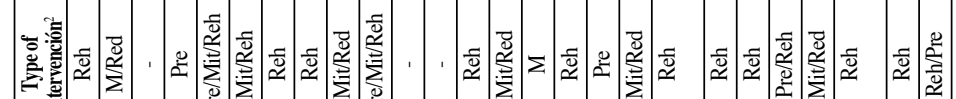

z) 2 .

8

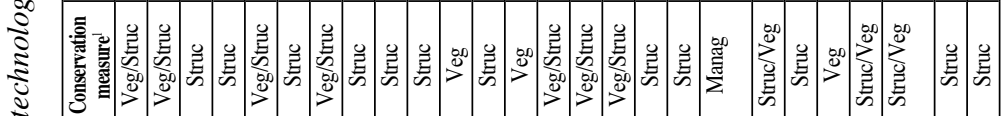

$\stackrel{2}{\stackrel{2}{2}}$

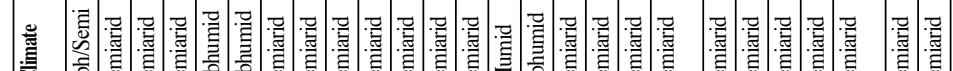

¿

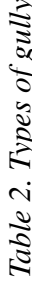

흔

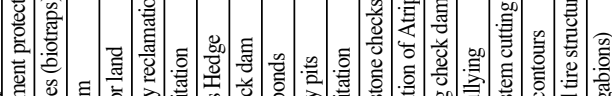

. ్ㅗㄹ

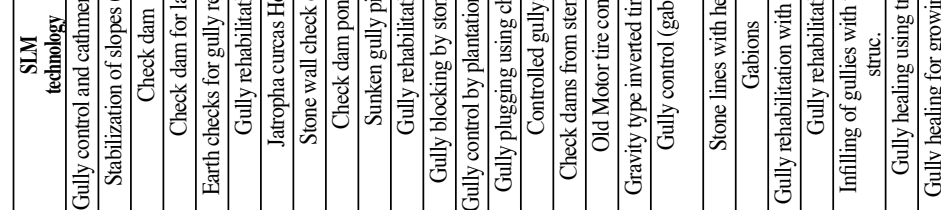

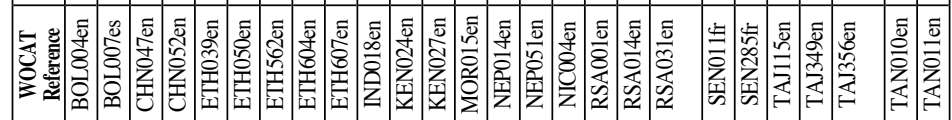

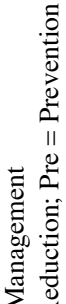

荧苞范

\& 11 늘

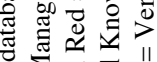

出芯鸪》

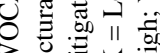

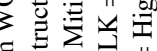

苛 II II

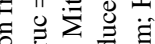

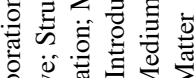

$\sum \Sigma \Sigma$

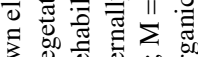

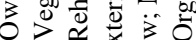

ن. II II

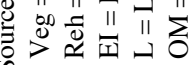




\section{Results}

Gully control measures documented in the WOCAT database are grouped in three classes: (i) structural, (ii) vegetative and (iii) structural/vegetative. In the next paragraphs, the impacts and effectiveness of the three different groups of control measures are analysed.

\subsection{Cost-benefit analysis and implementation and maintenance effects}

An important factor constraining the implementation and maintenance of the different technologies is their cost, since in many cases farmers alone cannot afford them. Our evaluation of examples from the WOCAT database indicates that combined technologies of vegetative and structural types are usually cheaper in their establishment cost than the purely structural ones, especially the construction of stone walls that are usually the most expensive technologies. The cases with detailed costs information provided in WOCAT indicate that the establishment cost usually lies between $\$ 100$ and $\$ 1000$ per ha, only in $35 \%$ of the cases the cost is between $\$ 1000$ and $\$ 10,000$ per ha, although the exact costs of course strongly depend on the exact type of measure and their extent, or density, of implementation. Once the technology is in place, the annual maintenance cost is not very high: in 50\% of cases, it is less than $\$ 100$ per ha, and for the other $50 \%$ between $\$ 100$ and $\$ 1000$ per ha.

Of special interest is the cost-benefit ratio of each of the implemented measures. During establishment, $30.7 \%$ of the documented technologies reported a negative costbenefit ratio on the short-term, while in $19.2 \%$ of cases it was neutral, and in $50 \%$ there was a positive ratio (Fig. 1). However, on the long-term, the cost-benefit ratio of establishment was considered positive in $46.2 \%$ of cases and very positive for $53.8 \%$ of cases. With respect to short-term maintenance, in $65.4 \%$ of cases it is positive and in the long-term the percentage rises to $92 \%$ of all cases (Fig. 1). The most optimal costbenefit ratios were reported for combined vegetative-structural techniques.

\subsection{Impacts of the gully control technologies}

Different technologies, once applied, can have positive or negative impacts. The impacts to be considered are: i) socio-economic and productive; ii) socio-cultural; iii) ecological; and iv) off-site impacts. WOCAT differentiates between high medium and low impacts. Impacts are considered high $(\mathrm{H})$ when they are above $50 \%$, medium $(\mathrm{M})$ between 20 and 50\%, and low (L) if a measure results in a change between 5 and $20 \%$ in a variable.

i) Socio-economic and production impacts. In most cases, gully control provides very positive benefits, with a very high impact on farm income, crop yield, quantitative fodder production, and wood production. With a moderate impact, and in a smaller number of cases, positive impacts are reported for the reduced risk of production failure, forage quality, diversification of income sources, the simplification of farming operations, and the availability/quality of irrigation water. Finally, with a low impact and in a very small number of cases, we can include the reduction of agricultural expenses (inputs), job creation and farm employment, and improvement of water quality and availability (Fig. 2). 


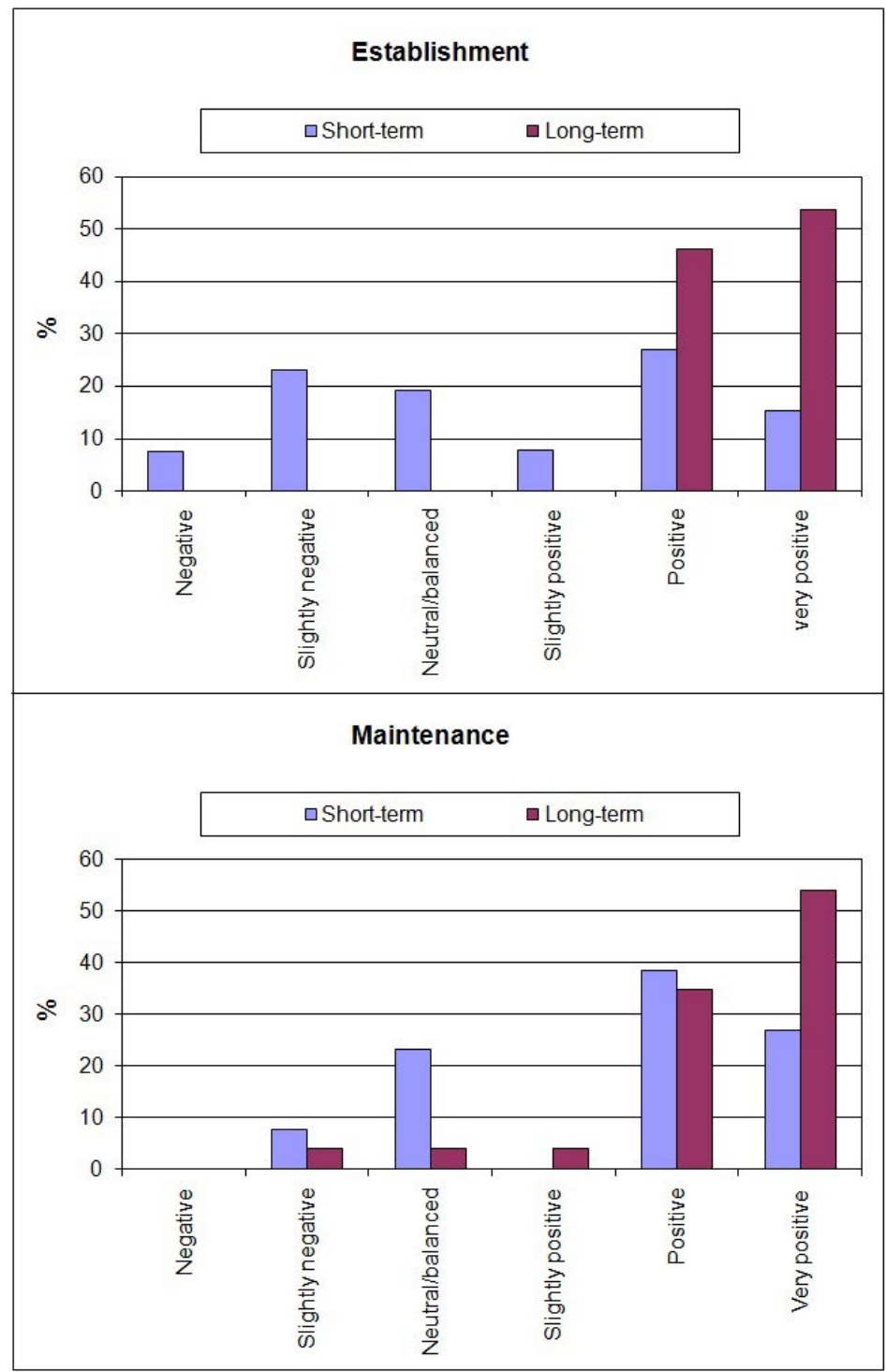

Figure 1. Cost-benefit ratios for the establishment and maintenance of gully control measures.

Some of the technologies discussed also have some disadvantages. The most negative effects are the increase in labour restrictions associated with eight of the technologies and the decrease in the productive area for five of them. Other aspects cited as disadvantages are the hampering of agricultural operations (3 cases), increased economic inequality and expenditure on agricultural inputs (2 cases), blockage of the movement of herds/flocks, the establishment work required, or the increased risk of harvest loss (1 case) (Fig. 2). 


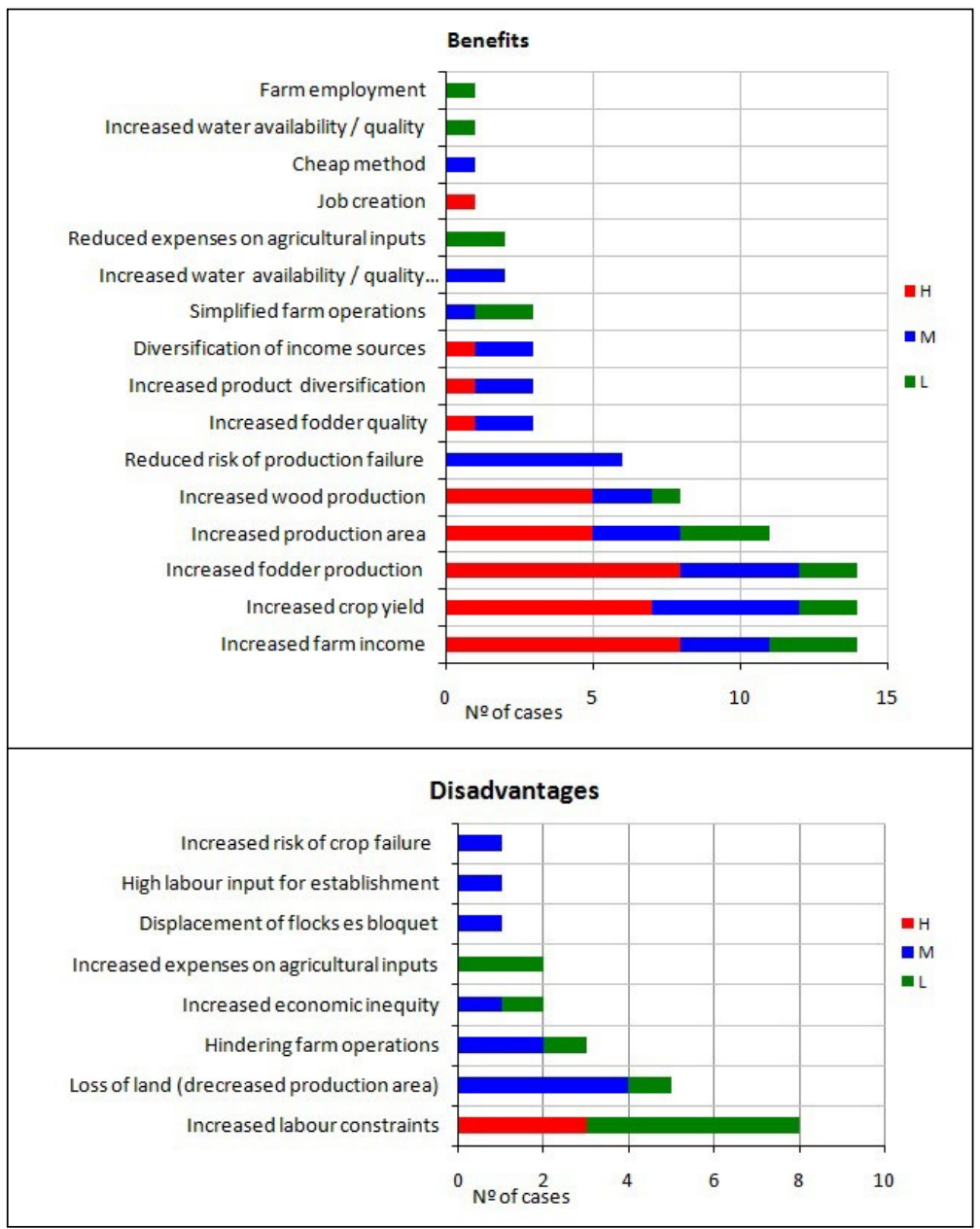

Figure 2. Productive and socio-economic benefits and disadvantages.

ii) Socio-cultural impacts. From the socio-cultural point of view and with a highmedium positive impact, for the majority of the analysed cases, the greater knowledge and awareness of the importance of soil conservation and erosion and the strengthening of community institutions stand out. In a smaller number of cases, and with a high impact, is the increase in food security, while the strengthening of national institutions and the improvement of disadvantaged socio-economic groups has a moderate impact. At the same time, in other cases, cultural opportunities, conflict mitigation, health, and recreational opportunities are enhanced (Fig. 3). The socio-cultural disadvantages are scarce: in just one case, a reduction of grazing land, the need for specialized labour, or a lack of benefit for the farmers were mentioned. In three cases, with a low average impact, increased socio-cultural conflicts were mentioned (Fig. 3). 


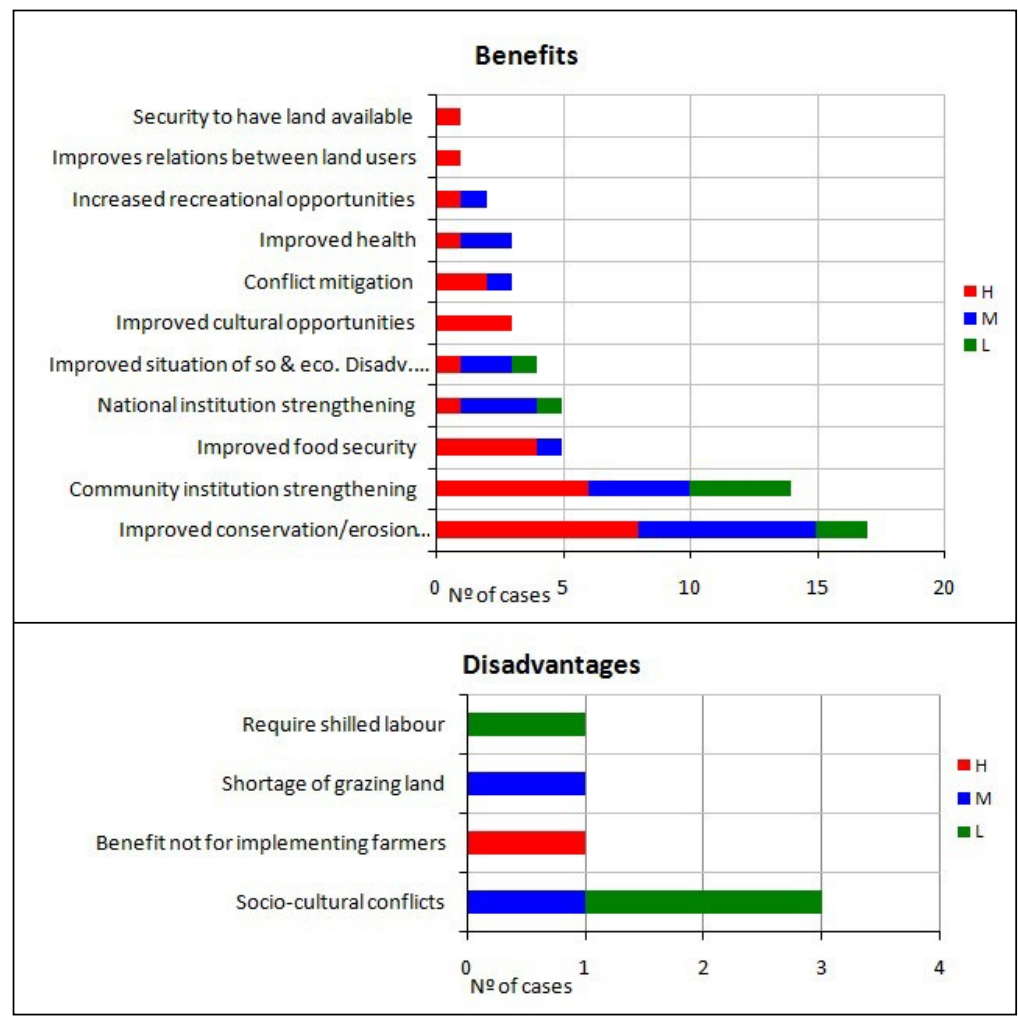

Figure 3. Socio-cultural benefits and disadvantages.

iii) Environmental impacts. The environmental benefits of gully control technologies are most prominent. In order of importance the following impacts are highlighted: reduction of soil loss, increase in soil moisture and coverage, reduction of runoff, biodiversity protection, reduction of adverse events, recharge of aquifers (especially with the construction of check dams), increased biomass, improvement in excess drainage water, or improvement in water harvesting and collection. With a lower impact, and in fewer cases, are the benefits of increases in soil fertility, nutrient cycle recharge, carbon sequestration, plant diversity, quantity and quality of water, or soil organic matter. Finally, in a smaller number of cases, are the positive impacts of increased numbers of beneficial species, reductions of evaporation, soil compaction and sealing, and wind speed, and increased animal diversity (Fig. 4).

The ecological disadvantages are very scarce. Two cases mentioned an increase in niches for pests (high impact) and in flooding (moderate impact). One case reported an increased competition among species (moderate impact) and (with low impact) competition for water, sunlight, and nutrients (Fig. 4). 
iv) Off-site impacts. In the majority of cases, and with high impact, the reduction of floods and sedimentation downstream are important off-site impacts of gully control. Damage is also reduced in neighbouring fields and in infrastructure, both public and private. Likewise, the buffering capacity is improved, the contamination of rivers and groundwater is reduced and, in some cases, the flow of runoff in the dry season increases together with the availability of water (Fig. 5). Only two disadvantages are mentioned (Fig. 5): the reduction in sediment production (in 4 cases) and the reduction of river flow (in 2 cases).

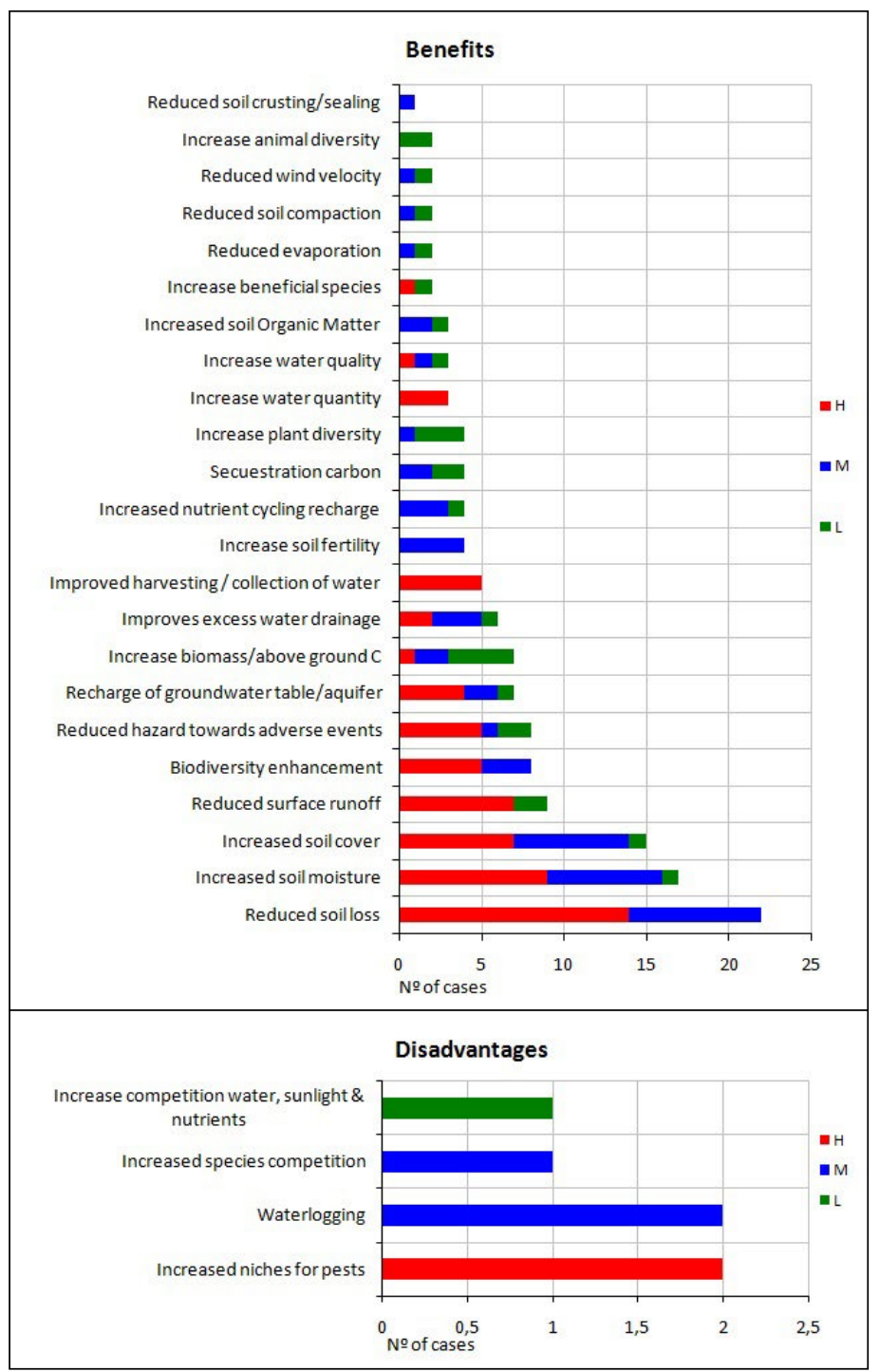

Figure 4. Environmental benefits and disadvantages. 


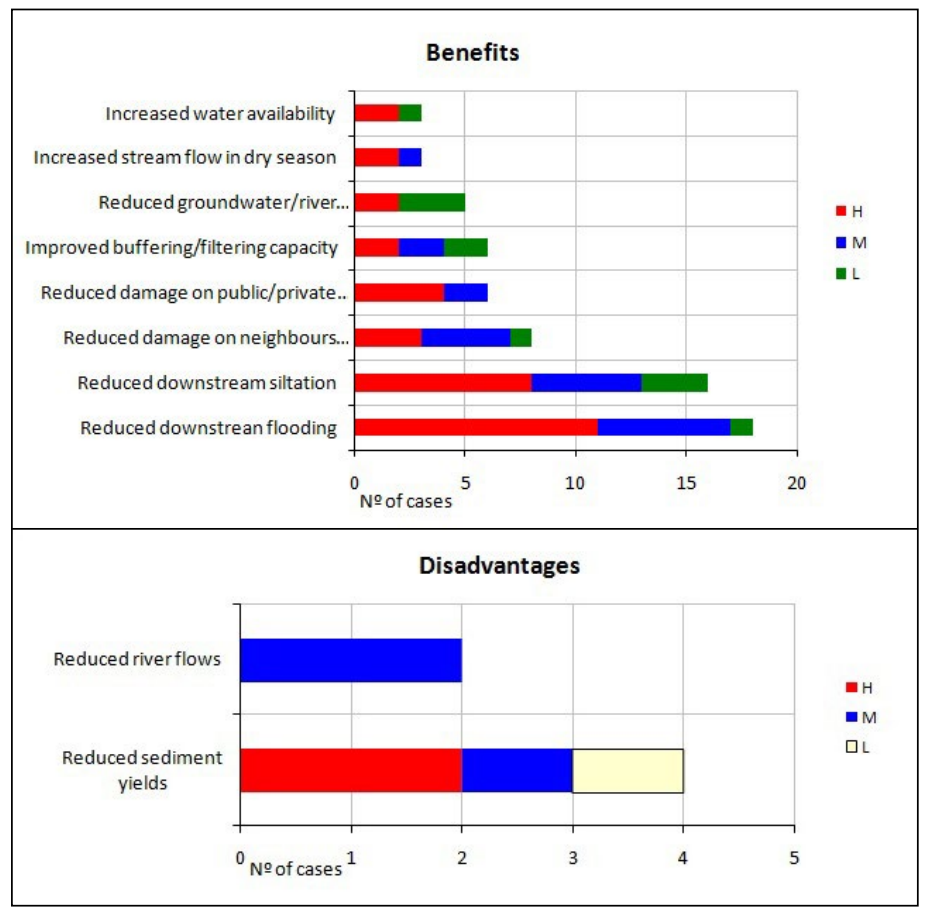

Figure 5. Off-site benefits and disadvantages.

\subsection{Ecosystem services related to gully control}

To assess the ecosystem services (ES) supported by the different gully control measures, we have considered the impacts shown in Figures 6 to 9 in relation to the four main groups of ES (provisioning, regulating, supporting and cultural) and building on the framework for the provision of ES from soil resources as presented by Dominati et al. (2010).

i) Provisioning services. Generally, in this category of ES are included production of food, fiber, fuel, and water. Gully erosion affects production in several ways, directly through the loss of land for production and indirectly through damage to crops and vegetation by sedimentation and floods downstream. Gully control measures protect both the availability of land for production and prevent damage to production areas. In order of importance, the impacts of gully control are most significant in relation to: (i) food supply, due to increased crop yield and reduced production failure; (ii) increased forage production; (iii) the provision of clean water - reduced pollution of rivers and groundwater, enhanced filtering, improved water quality; (iv) the provision of land by increasing the area of production; (v) increased timber yields; and (vi) the provision of more water through water harvesting and retention (Fig. 6). 


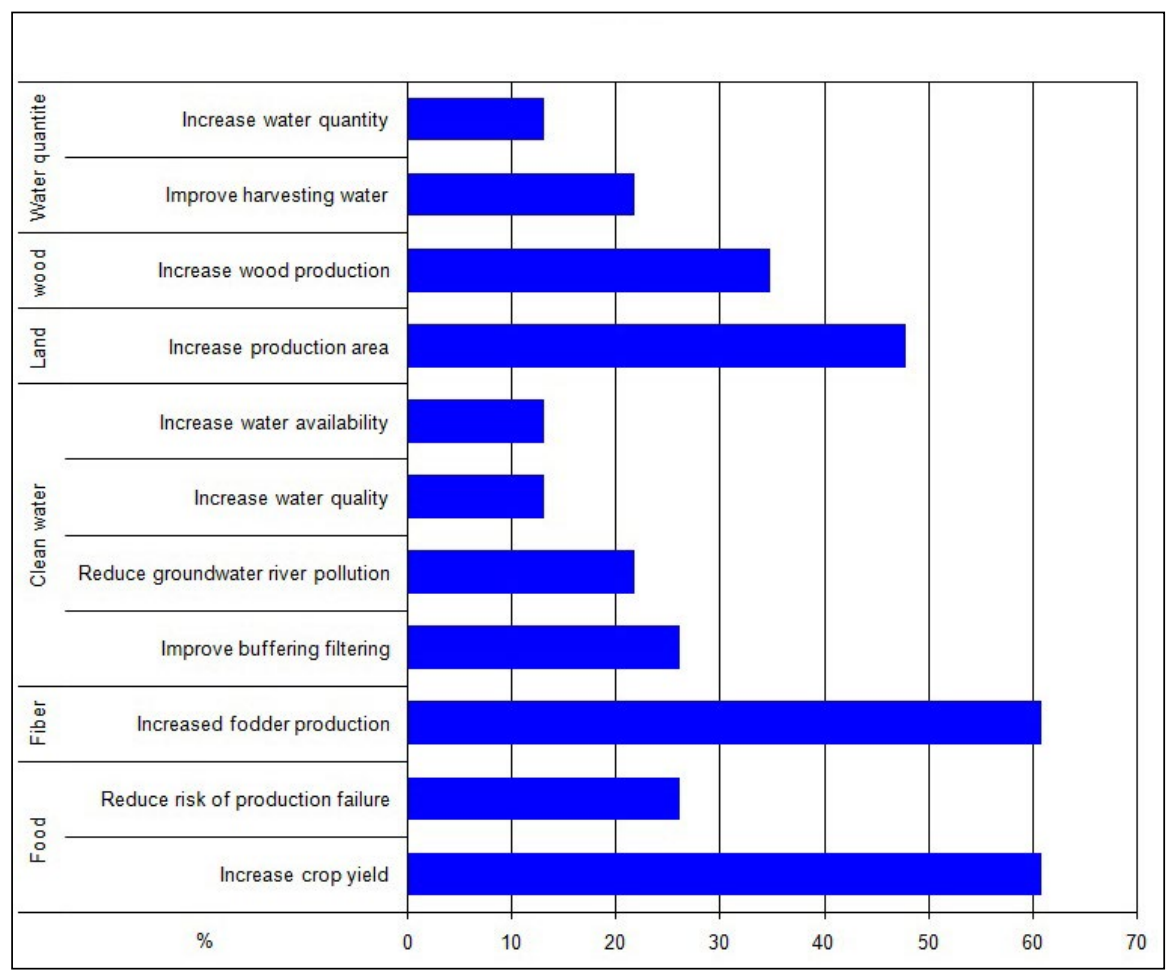

Figure 6. Provisioning ecosystem services.

ii) Regulating ecosystem services. Regulating ecosystem services represent amongst the most important aspects of gully control. The application of some of gully control techniques can improve the regulation of climate, natural hazards, water and nutrient cycling, soil erosion, biodiversity, and health. Climate regulation can arise through increases and maintenance of organic carbon in the vegetation cover and in soil organic matter. Natural hazards (Fig. 7) constitute one of the main regulatory systems, through the reduction of floods, sedimentation, damage to neighbouring fields, risks of adverse events, and damage to infrastructure. Water regulation is achieved by increasing soil moisture, recharging of the water table, improving excess water drainage, reducing evaporation losses, or increasing the availability of water for irrigation. Regulation, or prevention, of soil erosion is the most important ES provided by gully control. In almost all cases analysed (96\%), a reduction of soil erosion is mentioned. The reduction of runoff and, to a lesser extent, the reduction of wind speed and of the compaction and sealing of soils are also highlighted, evidently influencing runoff and erosion. The regulation of biodiversity has minor effects, resulting in some cases from the increase in the diversity of plants, animals, and beneficial species used for gully control. The improvement of health is cited in only three cases. 


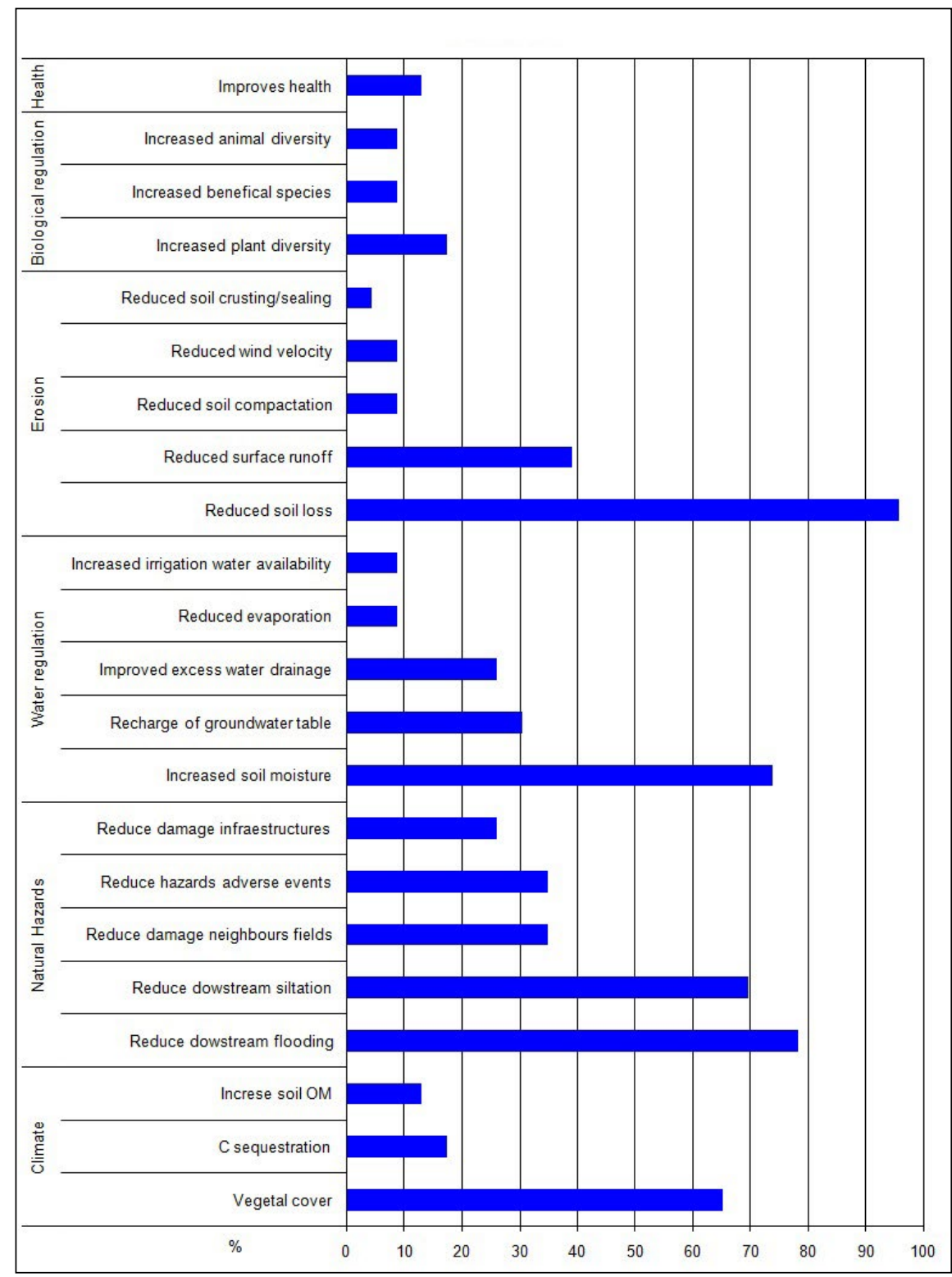

Figure 7. Regulating ecosystem services.

iii) Supporting ecosystem services. Although supporting ES are not principally affected by gully control in most cases, some of the benefits include: (i) protection of genetic pools due to improved biodiversity; (ii) enhanced nutrient cycling by recharging the nutrient cycle; (iii) soil formation through increased vegetation cover and enhanced soil quality facilitating soil biodiversity and processes of soil formation (Fig. 8). 


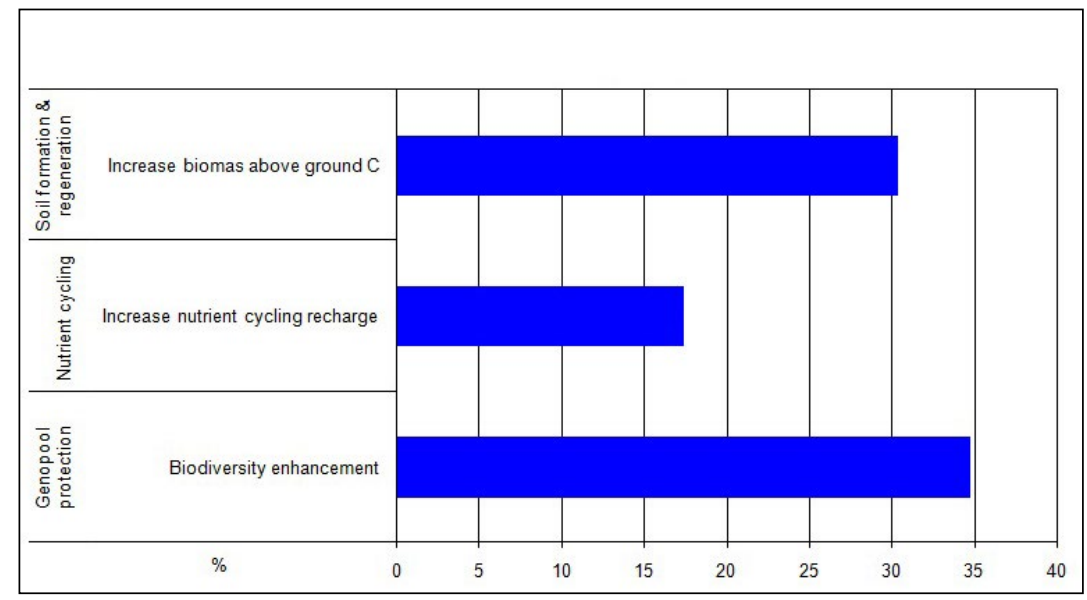

Figure 8. Supporting Ecosystem Services affected by gully control measures.

iv) Cultural ecosystem services. CulturalES include the potential for recreation, education and the strengthening of institutions. It is worth noting that implementing gully control measures contribute to a greater knowledge of soil erosion and conservation processes and their impacts (74\% of the cases) and the strengthening of community institutions to prevent land degradation in general (61\% of cases) (Fig. 9).

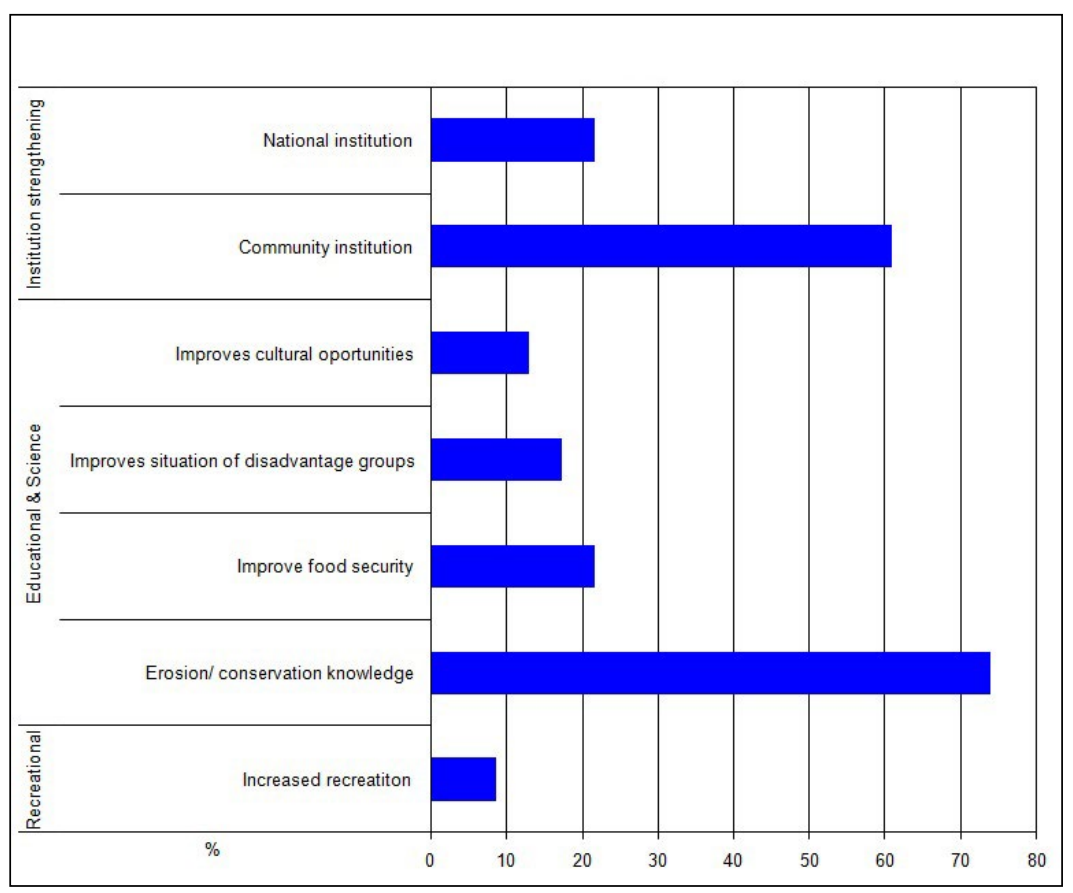

Figure 9. Cultural ecosystem services. 


\subsection{Expert and land owners opinions on the need for gully control}

WOCAT documents farmer and expert opinions regarding the main land degradation problems in each area that make it necessary to implement gully control measures. Table 3 summarizes these views and although experts and farmers show, in general, a consensus in the identification of the problems, some differences are evident. Experts often point to the causes of erosion, while farmers focus more on the problems that this erosion poses to them, such as the loss of agricultural land or the inability to produce food. In many cases, linked effects are mentioned; for example, as a result of overgrazing or cultivation in unsuitable areas, erosion processes can occur, leading to a loss of cultivated land and poor crop yields, food insecurity, or destruction of roads. One of the main drivers of land degradation and gully formation, indicated by both experts and farmers, is overgrazing.

Table 3. Main drivers and impacts of land degradation by gullies documented in WOCAT.

\begin{tabular}{|c|c|c|c|}
\hline Country & Cases & Expert opinion & Farmer's opinion \\
\hline Bolivia & 2 & $\begin{array}{l}\text { Overgrazing, agriculture on steep } \\
\text { slopes, erosion, floods }\end{array}$ & No opinion \\
\hline China & 2 & Serious gully erosion & Loss of agricultural land \\
\hline Ethiopia & 5 & $\begin{array}{l}\text { Overgrazing, monocultures, soil } \\
\text { erosion, low fertility, cultivation in } \\
\text { zones prone to erosion }\end{array}$ & $\begin{array}{l}\text { Land erosion and degradation, } \\
\text { scarce vegetation cover, demograph- } \\
\text { ic pressure, overgrazing, loss of } \\
\text { productivity }\end{array}$ \\
\hline India & 1 & Gully development & $\begin{array}{l}\text { Sedimentation of harvest and unpro- } \\
\text { ductive land }\end{array}$ \\
\hline Kenya & 2 & Erosion, overgrazing, loss of fertility & $\begin{array}{l}\text { Lack of tools and credit, poor com- } \\
\text { munication }\end{array}$ \\
\hline Morocco & 1 & $\begin{array}{l}\text { Hydraulic erosion, abandonment of } \\
\text { land, desertification }\end{array}$ & Yield decline, lack of water \\
\hline Nepal & 2 & $\begin{array}{l}\text { Small areas of land, low fertility, } \\
\text { intense precipitation }\end{array}$ & Overgrazing \\
\hline Nicaragua & 1 & $\begin{array}{l}\text { Soil degradation, gullies in culti- } \\
\text { vated land, lack of knowledge and } \\
\text { resources }\end{array}$ & No opinion \\
\hline $\begin{array}{l}\text { South } \\
\text { Africa }\end{array}$ & 3 & $\begin{array}{l}\text { Overgrazing, poor planning of land } \\
\text { use, population density }\end{array}$ & $\begin{array}{l}\text { Overgrazing, drought, shortage of } \\
\text { land, insecurity }\end{array}$ \\
\hline Senegal & 2 & Unusable land due to gully erosion & $\begin{array}{l}\text { Erosion, loss of fertility, destruction } \\
\text { of means of communication }\end{array}$ \\
\hline Tajikistan & 3 & $\begin{array}{l}\text { Soils very prone to erosion, intense } \\
\text { precipitation, overgrazing }\end{array}$ & $\begin{array}{l}\text { Water shortage, unproductive soils, } \\
\text { serious erosion, lack of infrastruc- } \\
\text { ture to stop erosion }\end{array}$ \\
\hline Tanzania & 2 & Formation and expansion of gullies & Formation and expansion of gullies \\
\hline
\end{tabular}

Source: Own elaboration from the WOCAT database 


\section{Discussion}

\subsection{Cost-benefit analysis of gully control}

Generally, gully erosion is more difficult and costly to control than sheet or rill erosion (Lal, 1992), so the control of gullies is expensive and the farmer, in most cases, lacks the resources necessary for the rehabilitation of these areas (BravoEspinosa et al., 2010). Farmers often prioritize their immediate need to produce food and income and do not invest in the restoration of gullies, especially in the case of subsistence farming or under conditions with insecure land tenure (Moges and Holden, 2008). This means that preventive or control measures for gullies should yield shortterm benefits in terms of increased yields, availability of more land for cultivation, and reliable crop yields through better use of soil and water (Pathak et al., 2005). According to Desta and Adugna (2012), the cost-benefit ratio of gully control should be carefully evaluated. Techniques that exercise maximum control with the least possible cost should be prioritised (Heede, 1982). Costly measures of gully control and/or restoration have sometimes been unsuccessful (Heede, 1982; Lal, 1992). On the other hand, other studies (e.g. Mora Jordano et al., 2013) have demonstrated that some control measures can be implemented with little technological knowledge or skills and at costs affordable to many owners and with reasonable benefits.

When evaluating the real costs and benefits of the various means of rehabilitation of gullies, it is necessary to contemplate the different ES that the control contributes. Zhou et al. (2009) stressed that in a cost-benefit evaluation of soil conservation practices it is necessary to consider the economic value of the soil that is lost and the damage generated by off-site erosion to reflect the true value of long-term conservation practices. In Ethiopia, Yitbarek et al. (2012) evaluated the on-site cost of erosion in gullies in addition to the cost-benefit ratio of rehabilitation, considering the loss of yield as well as the cost of the fertilizers needed to replace the eroded soil nutrients. Kennedy et al. (2001), in a study in Austria, commented that although soil conservation measures can be costly, the environmental damage, aesthetic impact, and the cost of restoring roads due to impacts by erosion can be much higher. Therefore, the cost-benefit evaluation shows how investments in the rehabilitation of gullies may be an economically viable in some cases. Ohde (2011) considered that agricultural lands provide society with an abundance of services. While agro-ecosystems are currently managed primarily for the production of food, fibre and fuel, they can also provide many other ES benefits, such as carbon sequestration, improved water quality, erosion and flood control, and habitats for flora and fauna (Boody et al., 2005; MA, 2005). Hence, is necessary to prevent erosion or to rehabilitate already eroded areas, especially those that have highest erosion rates and contribute most to off-site damages by sedimentation and floods. The use of an ES approach to gully control, where the multiple impacts and costs of degradation are considered, may allow a more appropriate assessment of the actual cost-benefit ratio for the farmer and for society as a whole (Hein, 2007).

Although the need to control gullies is beyond doubt since the cost-benefit ratio is often positive on the long term and gully control supports crucial ES, farmers often 
face multiple barriers for implementation of prevention or restoration measures. Most important barriers include limited access to capital, scarce direct benefits, land tenure insecurity, limited technical support, and poor community participation (Haregeweyn et al., 2015; Sanz et al., 2017). Hansen and Law (2008) mentioned the need to share the costs between farmers and the administrative bodies that facilitate the various treatments. Cotler et al. (2011) argued that in Mexico the institutional participation in soil rehabilitation issues is weak and discontinuous, and in fact has accentuated soil degradation. Therefore, they stressed the need to increase and strengthen participatory development strategies to ensure that conservation and, in general, the sustainable use of soils occupies an important place in the economic and political national agendas. Schmiedel et al. (2016), in a study of the ecological and financial impacts of soil erosion and its control in South Africa, demonstrated how the costs of restoration measures, although involving low-cost material and local labour, require financial support from the public sector through an accessible and sufficient payment for protected ES. This is justified by the fact that the implementation of these techniques by the owners benefits society as a whole, for example by reducing the risks of flooding. Stakeholders should therefore continue to invest in, and be incentivised and supported to apply appropriate gully rehabilitation, and prevention management techniques, to ensure the benefits and the use of surrounding farmland.

Our evaluation shows that the cost-benefit ratio of all three groups of technologies (i.e. vegetative, structural, vegetative/structural) is positive to very positive in both their establishment and maintenance phase, and in the short- and long-term. This confirms the results presented by Giger et al. (2015) who specifically assessed the economic benefits and costs of SLM technologies (including gully control) based also on analysis of the WOCAT database. Overall, both land users and experts perceive that most SLM practices for gully control described in the WOCAT database have benefits that justify the required investments. Nevertheless, to make such investments, the land users require stable economic conditions and secure tenure rights, since the adoption of these technologies is usually a gradual process that lasts for many years.

\subsection{Analysis of different gully control measures}

In the cases analysed, most of the control measures are structural or structural/ vegetative, or, to a lesser extent, purely vegetative (Table 4). Structural measures have a primary preventive function, while the main function of vegetative and structural/ vegetative measures is rehabilitation.

A broad range of gully control techniques are described in detail in several manuals (e.g. FAO, 2000; Pathak et al., 2005; Sagarpa, 2009; Gómez Gutiérrez et al., 2011; Cisneros et al., 2012; Desta and Adugna, 2012). 
Table 4. Literature review of studies involving analysis of the measures used for gully control.

\begin{tabular}{|c|c|c|c|c|}
\hline Reference & Structural & Vegetative & $\begin{array}{c}\text { Structural/ } \\
\text { vegetative }\end{array}$ & Country \\
\hline Addis et al., 2015 & & & $\mathrm{X}$ & Ethiopia \\
\hline $\begin{array}{l}\text { Belmonte Serrato and Romero Díaz, } \\
2009\end{array}$ & $\mathrm{X}$ & & & Spain \\
\hline Blanco-Canqui et al., 2016 & & $\mathrm{X}$ & & USA \\
\hline Bravo Espinosa et al., 2010 & & $\mathrm{X}$ & & Mexico \\
\hline Burkard and Kostaschuk, 1997 & $\mathrm{X}$ & & & USA \\
\hline Burylo et al., 2012 & & $\mathrm{X}$ & & France \\
\hline Castillo et al., 2007 & $\mathrm{X}$ & & & Spain \\
\hline Castillo et al., 2014 & $\mathrm{X}$ & & & Spain \\
\hline Cisneros et al., 2012 & & $\mathrm{X}$ & & Argentina \\
\hline Daniels and Giliam, 1996 & & $X$ & & USA \\
\hline De Baets et al., 2007 & & $\mathrm{X}$ & & Spain \\
\hline De Baets et al., 2009 & & $X$ & & Spain \\
\hline Ehrensperger et al., 2015 & & $\mathrm{X}$ & & Ethiopia \\
\hline Ene and Okogbue, 2015 & $X$ & & & Nigeria \\
\hline Erktan et al., 2013 & & $\mathrm{X}$ & & France \\
\hline Frankl et al., 2014 & $\mathrm{X}$ & & & Ethiopia \\
\hline Gómez Gutiérrez et al., 2011 & $\mathrm{X}$ & & & Spain \\
\hline Kennedy et al., 2001 & $\mathrm{X}$ & & & Australia \\
\hline Leguédois et al., 2008 & & $\mathrm{X}$ & & Australia \\
\hline Mekonnen et al., 2015 & & & $\mathrm{X}$ & Various \\
\hline Meyer et al., 1995 & & $\mathrm{X}$ & & ¿? \\
\hline Mongil et al., 2015 & & $\mathrm{X}$ & & Spain \\
\hline Mora Jordano et al., 2013 & & & $X$ & Spain \\
\hline Morris and Jonson, 1943 & $\mathrm{X}$ & & & USA \\
\hline Nyssen et al., 2004 & $\mathrm{X}$ & & & Ethiopia \\
\hline Ohde, 2011 & & $X$ & & USA \\
\hline Okagbue and Uma, 1987 & & & $X$ & Nigeria \\
\hline Poesen, 2011 & & & $\mathrm{X}$ & Various \\
\hline Polyakov et al., 2014 & $\mathrm{X}$ & & & USA \\
\hline Romero Diaz et al., 2007 & $\mathrm{X}$ & & & Spain \\
\hline Schmiedel et al., 2016 & & $\mathrm{X}$ & & South Africa \\
\hline Sheng and Liao, 1997 & & & $X$ & China \\
\hline Weinhold, 2007 & & & $\mathrm{X}$ & USA \\
\hline Pathak et al., 2005 & $X$ & & & India \\
\hline Yuan et al., 2009 & & $\mathrm{X}$ & & Various \\
\hline
\end{tabular}

Source: Own elaboration 


\subsubsection{Structural measures}

Structural gully control measures usually consist of the placement of loose stones, stone walls and barriers, gabions, check-dams, sandbags, or old tires. However, dikes are often the most commonly used measures. They are generally constructed transversally to the gullies in order to control the flow of runoff, decrease the longitudinal gradient, retain the eroded sediments upstream, conserve soil, and improve soil characteristics (Romero Díaz et al., 2007). There are examples of successful restoration projects in gullies using check dams (Heede, 1977; Burkard and Kostaschuk, 1997; Weinhold, 2007; Polyakov et al., 2014). However, several authors have shown how check-dams may favour incision and erosion downstream or lateral of the dam (e.g. García Ruíz and Puigdefábregas, 1985; Martínez Castroviejo et al., 1990; Romero Díaz et al., 2007; Boix-Fayos et al., 2007; Belmonte Serrato and Romero Díaz, 2009). Other studies mention that in areas with favourable climatic conditions for vegetative techniques (reforestation), check dams are usually relatively expensive and, although they are effective in sediment retention, they have a short life expectancy due to their rapid siltation (Quiñonero et al., 2016). In other cases, structures may collapse due to faults in their construction (Nyssen et al., 2004) or due to piping processes (Sherard et al., 1972). In areas prone to piping processes, experiments with subsurface geo-membrane placement have been performed (Frankl et al., 2014). Yet, application of geoengineering structures for gully control does not always give good results as was illustrated by Godwin Ezekwesili and Celestine Obialo (2015) who reported that many structures were destroyed and new ravines appeared near existing ones in a study in Nigeria. This corroborates the opinion of Gómez Gutiérrez et al. (2011) who mention that an isolated retention dam alone is not a gully control measure if it is fed by other upstream waters against which measures have not been taken.

Desta and Adugna (2012) stressed the importance of good maintenance of the gully control structures. Structures built in gullies for stabilization should be checked for damage, especially during rainy seasons and after heavy storms. Damaged dams must be repaired immediately to avoid the eventual risk of collapse with possible domino effects on check dams downstream.

\subsubsection{Vegetative measures}

The vegetative measures consist mainly of the planting of grasses, shrubs, and trees in the bottom of the gully, in the headwaters, or in the margins. The principal effects of these vegetative measures are interception of rain (Belmonte Serrato and Romero Díaz, 2013), increased infiltration of water into the soil, increased soil roughness, reduction of runoff and of erosion by concentrated flows (Styzcen and Morgan, 1995), filtering of nutrients, sediment retention (Daniels and Gilliam, 1996; Rey, 2003; Blanco-Canqui et al., 2006), and if sufficiently dense vegetation cover is used a significant the reduction of hydrological connectivity (Ohde, 2011).

It is evident that vegetation plays an important regulatory role in the control of erosion (De Groot et al., 2002) and is a factor of great influence on the erosion rates on slopes prone to instability (Thornes, 1990; Morgan, 1995), and has been used for decades in ecological restoration of degraded lands (Coutancier, 2004; Stokes et al., 2010). Several 
studies recommend the establishment of biophysical control barriers in gullies and slopes (Pathak et al., 2005; De Baets et al., 2006), because they promote sedimentation and the growth of native vegetation, which creates new hydraulic conditions that modify the transport capacity in the channel, as long as it is accompanied by diversion and control of the overland flow upstream.

The effects of vegetation are manifold (Cisneros et al., 2012). The establishment of vegetation exerts a stabilizing influence on soil materials through the action of both the living and dead fractions, in both the surface and soil layers. Thus, in the stabilization of gullies, the architectural properties of the root systems are very important (De Baets et al., 2007; Burylo et al., 2012). Some species may be more efficient in soil stabilization than others, and may have a stronger impact on erosive dynamics and ecosystem stability (De Baets et al., 2009; Stokes et al., 2009). De Baets et al. (2009) demonstrated how the grasses Stipa tenacissima and Lygeum spartum, and the shrub Salsola genistoides would be very suitable plant species to control erosion in gullies. In degraded areas, several authors have emphasized the need to identify the best species that contribute to the provision of ecosystem services (Díaz, 2006; Luck et al., 2009). Ehrensperger et al. (2015) analyzed the effectiveness of Jatropha barriers to rehabilitate canyons in northern Ethiopia, demonstrating that the introduction of this species is a cheap, effective technology regarding soil and water conservation in the rehabilitation of gullies, providing food, animal feed, fuel, and fiber, and having an additional function as a windbreak, which helps to reduce the loss of water by evaporation in semiarid areas. Dabny et al. (1996) and Ritchie et al. (1997) showed that vetiver (Vetiveria zizanioides) and miscanthus (Miscanthus sinensis) planted close to the areas of flow concentration were effective, causing the deposition of eroded sediments and preventing the incision of the gullies. Leguédois et al. (2008) studied the efficacy of sediment traps through the use of buffer strips, concluding that - even for intense rainfall events - tree belts are very efficient. Knight et al. (2010) verified the capacity of the remaining riparian forests, with and without a grass filter, to diminish the concentrated surface runoff and thus the initiation of gullies. Meyer et al. (1995) analysed the effectiveness of narrow hedges of tall and rigid species to trap sediments, showing that they have great potential to retard runoff and reduce sediment losses. Richet et al. (2016) noted the role of vegetative barriers comprised by dense shrub hedges in reducing runoff and erosion, and indicated how the effectiveness of this measure is greater in traps that are placed immediately downstream of the erosion sources.

Bravo Espinosa et al. (2007) suggested a scheme to stabilize slopes and reduce erosion in gullies in a micro-catchment in Mexico. This scheme included planting plant species that showed good development in the slopes and gully bottoms, but the authors mentioned that for these measures to be effective grazing must be eliminated. Mongil et al. (2015) evaluated a 50-year-old forest and gully restoration in Spain using Pine trees. The current state of this restoration demonstrates the rehabilitation of the ecosystem and the important reduction of the problems of concentrated erosion. Other studies have focused on introducing plant barriers consisting of various species (Erktan et al., 2013), and concluded that morphological diversity does not increase sediment retention in marl 
gullies, while grass barriers with native species retain the sediment better and are the best strategy to initiate the ecological restoration of gullies.

Yuan et al. (2009) conducted a review of the effectiveness of vegetation traps for sediment retention in agricultural areas, and concluded that retention efficiency does not vary according to vegetation type. Rather, it declines as the size of the sediments decreases - suggesting that the retention efficiency depends on the soil type from which the sediment is derived and the rainfall energy, as the primary source of aggregate dispersion. Desta and Adugna (2012) mentioned that the recovery of vegetation will be slow on poor soils and therefore hampering gully control or restoration.

\subsubsection{Combined structural and vegetative measures}

The techniques that combine structural and vegetative measures undoubtedly have the highest efficiency (Nyssen et al., 2009; Zhang et al., 2010), although they are not always the most used. In the WOCAT database, they have been applied in 10 cases, corresponding to $38.5 \%$ of our sample.

In various experiments, the combination of vegetative and structural measures has shown positive results. In southern China, Sheng and Liao (1997) successfully implemented control measures combining check dam construction and reforestation. In Germany, Fiener and Auerswald (2006) combined soil conservation measures with structural measures and reduced sediment by $87 \%$; the effectiveness increased to $93 \%$ when vegetative measures were integrated. In lkali Creek (Colorado, USA), Weinhold (2007) evaluated a restoration project carried out 40 years earlier using a combination of structural and vegetative measures, and reported excellent results. Its success is explained by the large-scale basin wide implementation of measures and involving management of vegetation and grazing, perfection of hydraulic designs, the use of textiles to install vegetation in the bottoms of the channels, and the fertilization of the vegetation. Forty years after their construction, the structures had not failed, the ephemeral course had become perennial, and the erosion had been controlled. In Córdoba (Spain), Mora Jordano et al. (2013), in an experiment on the control of gullies through the use of forest vegetation and gabion check dams on farms, achieved control of the erosion in the gully head area and on its slopes. They reported specifically the important role of root development of the vegetation. At the same time, the revegetation had enhanced the biodiversity and substantially improved the landscape. In Ethiopia, Addis et al. (2015) found that structural erosion control measures along with biological measures resulted in a reduction of soil loss and the stabilization of gully expansion providing an important benefit to maintain crop productivity. In the North Cape province of South Africa, Schmiedel et al. (2016) reported that, two years after the application of the combined restoration measures, soil depth and vegetation cover had increased. Mekonnen et al. (2015) reviewed the effectiveness of different sediment trapping measures (both structural and vegetative) for sediment retention and concluded that in most cases their efficiency is very high, with average values between $70 \%$ and $100 \%$ of trapped sediment. 


\subsection{Ecosystem services derived from gully control}

Our analysis illustrates that gully control measures especially benefit regulating ES (Fig. 10). However, the application of these technologies also improves our knowledge of soil erosion and conservation, helps strengthening institutions, (i.e. cultural ES) and, in some cases, enhance the supply of food, water, fiber, land, and wood products (i.e. provisioning ES). Gully control seems to be least relevant for supporting ES, although protection of genetic pools, soil formation and regeneration are worth mentioning.

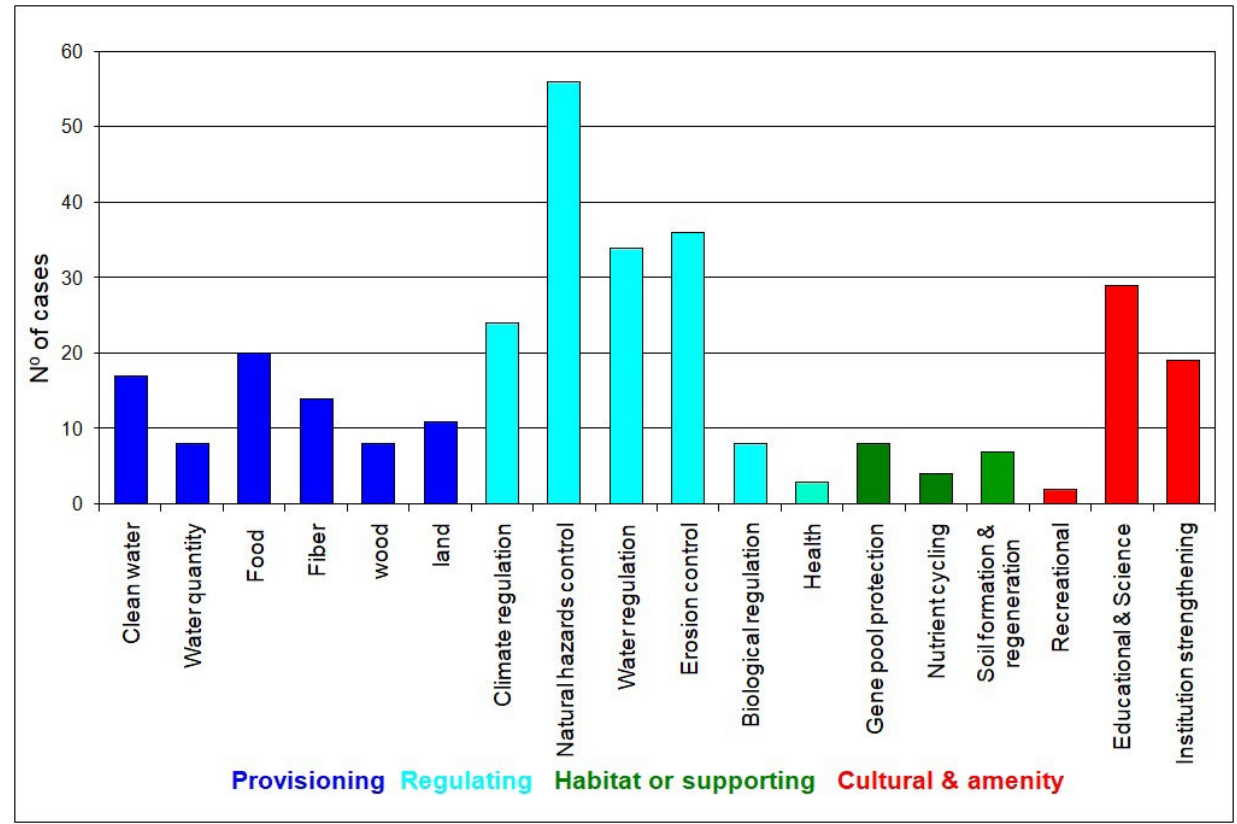

Figure 10. Main ecosystem services provided by gully control quantity.

The main objective of gully control is to stabilize them and prevent their further development by controlling the concentrated erosion processes by water. This study has verified that most of the techniques used to control such erosion have been quite effective, judging by the results documented in WOCAT and many other scientific studies. Erosion control exerts a series of chain effects mainly related to water regulation (surface runoff and underground flows), climate regulation (carbon sequestration due to improved soils and vegetation cover), and regulation of biological diversity (increased plant and animal diversity). All this contributes to regulating or minimizing the natural risks related to floods, sedimentation, damage in neighbouring fields, adverse events, and damage to infrastructure.

With regard to natural hazards, it is difficult to fully assess or account for all the costs to society, including costs by sedimentation in farmland, maintaining drains or 
drainage channels clean, damage to different infrastructures, the loss of capacity and functionality of reservoirs, or other damage caused by floods. Nevertheless, it is evident that implementation of gully control measures is certainly worth the effort if they can minimize the natural hazards including local and regional impacts.

\section{Conclusions}

Soil erosion and their on-site and off-site impacts is one of the major problems facing sustainable agriculture around the world today. Gully erosion is the most important water erosion process often contributing to major soil losses and sedimentation downstream. The "on site" effects mainly affect crop productivity and yields, and "off site" effects refer to increased flooding, reservoir siltation, damage to crops and infrastructure, and non-point source contamination.

In spite of the great number of existing studies on erosion processes in gullies, those related to their control are in the minority and there is still a need to investigate effective techniques to control, prevent or restore this type of erosion. The WOCAT database has shown to be a very important source of worldwide information, enabling global reviews and knowledge exchange regarding SLM practices and their effectiveness. We provided an evaluation of gully control technologies applied at a global level based on a representative sample of documented technologies in the WOCAT database and additional critical review of broader scientific literature. Our review based on expert assessments from WOCAT and additional review of scientific literature illustrates the effectiveness of a great variety of techniques - from structural, to vegetative, and combinations between vegetative and structural. Results indicate that application of combined vegetative/structural measures and catchment wide integrated implementation plans are most effective and contribute notably to soil and ware conservation.

It is important to highlight the opinions of both experts and farmers regarding the different technologies and the problems of land use that have led to different actions of gully control. Experts often point out the causes of erosion, while farmers focus more on how erosion affects them, such as the decline in usable land or crop yield. Experts and farmers agree on highlighting overgrazing as one of the fundamental causes of land degradation and gully formation in almost all countries.

Our evaluation emphasises that the implementation of gully control measures yields socio-economic production benefits, as well as socio-cultural, local ecological, and off-site benefits. Some, especially socio-economic, disadvantages of gully control measures are outweighed by the many advantages - particularly the increases in farmers' income, crop yields, or wood and forage production. The most compelling argument for farmers to adopt a measure and invest in soil and water conservation is to increase land productivity and provide economic benefits. From a socio-cultural point of view, farmers' knowledge of soil erosion and conservation is improved and community institutions are strengthened. The ecological and off-site benefits are the most important, particularly the reduction of soil loss, the increase in soil moisture and vegetation cover, and the reduction of floods and the societal risks derived from them. 
In general, the cost-benefit ratio of the different technologies is positive or very positive, especially in the long-term. However, despite their important benefits, it is not always possible to implement gully control measures because farmers or land users encounter multiple technological, economic, institutional and cultural barriers for implementation. Often farmers cannot assume the costs of implementation and maintenance, lack sufficient knowledge, or are in a situation with insecure land tenure. For this reason, institutional assistance is necessary to ensure that the most effective locally adapted measures can be implemented. To support and stimulate wide scale adoption of effective measures it is crucial to have detailed and reliable information on the costs and benefits at local and regional levels.

Therefore, the cost-benefit assessment should be made considering not only the monetary aspects of implementation and maintenance, but also the ES that the different gully control measures contribute locally and regionally to society as a whole. If these ES were evaluated and quantified in detail, the cost-benefit ratio would undoubtedly be even more positive.

The implementation of the different gully control measures strengthens important Ecosystem Services (ES) in all categories, but especially regulating ES stand out (e.g. erosion, water cycling, natural hazards, floods).

\section{Acknowledgments}

We acknowledge support received from the Spanish Ministry of Science and Innovation to the ADAPT project (CGL2013-42009-R) and by the Seneca Foundation to the project CAMBIO (118933/JLI/13).

\section{References}

Addis, H.K., Adugna, B., Gebretsadik, M., Ayalew, B. 2015. Gully Morphology and Rehabilitation measures in different agroecological environments of Northwestern Ethiopia. Applied and Environmental Soil Science, Article ID 789479, 8 pp. https://doi.org/10.1155/2015/789479.

Avni, Y. 2005. Gully incision as a key factor in desertification in an arid environment, the Negev highlands, Israel. Catena 63, 185-220. https://doi.org/10.1016/j.catena.2005.06.004.

Baade, J., Barsch, D., Maüsbacher, R., Schukraft, G. 1993. Field experiments on the reduction of sediment yield from arable land to receiving water courses (N-Kraichgau, SW-Germany). In: S. Wicherek (Ed.), Farm Land Erosion in Temperate Plains and Hills. Elsevier, Amsterdam, pp. 471-480.

Bakker, M.M., Govers, G., Rounsevell, M. 2004. The crop productivity-erosion relationship: an analysis based on experimental work. Catena 57, 55-76. https://doi.org/10.1016/j. catena.2003.07.002.

Bakker, M.M., Govers, G., Jones, R.A., Rounsevell, M. 2007. The effect of soil erosion on Europe's crop yields. Ecosystems 10, 1209-1219. https://doi.org/10.1016/j.catena.2003.07.002.

Belmonte Serrato, F., Romero Díaz, A. 2009. Erosive and environmental impacts of hydrological correction check dam. In: W.P. Hayes, M.C. Bornes (Eds.), Dams: Impacts, Stability and Design. Nova Science Publishers, Hauppauge, pp. 161-178.

Belmonte Serrato, F., Romero Díaz, A. 2013. Interceptación de la lluvia por la vegetación en España. IEA (Instituto Euromediterráneo del Agua), Murcia. 
Blanco-Canqui, H., Gantzer, C.J., Anderson, S.H. 2006. Performance of grass barriers and filter strips under interrill and concentrated flow. Journal of Environmental Quality 35 (6), 19691974. https://doi.org/10.2134/jeq2006.0073.

Boix-Fayos, C., Barbera, G.G., López-Bermúdez, F., Castillo, V. 2007. Effects of check dams, reforestation and land-use changes on river channel morphology: Case study of the Rogativa catchment (Murcia, Spain). Geomorphology 91 (1-2), 103-123. https://doi.org/10.1016/j. geomorph.2007.02.003.

Boody, G., Vondracek, B., Andow, D.A., Krinke, M., Westra, I., Zimmerman, J., Welle, P. 2005. Multifunctional Agriculture in the United States. BioScience 55 (1), 27-38. https://doi. org/10.1641/0006-3568(2005)055[0027: MAITUS]2.0.CO;2.

Bravo-Espinosa, M., Serrato-Barajas, B., Medina-Orozco, L., Fregoso-Tirado, LE. 2007. Rehabilitación de taludes en cárcavas de la subcuenca de Cointzio, Michoacán. In: M. Bravo Espinosa, C. Sánchez-Brito, F.O. Rulfo Vilchis, L.E. Fregoso Tirado (Eds.), Bases metodológicas para el manejo integral de cuencas hidrológicas. Libro Técnico No. 4. INIF AP.Uruapan, Michoacán, México, pp. 214-226.

Bravo-Espinosa, M., Mendoza, M.E., Medina-Orozco, L., Sáenz-Reyes, T. 2010. Characteristics and Control of Gully Erosion. Terra Latinoamericana 28, 281-285.

Brown, L.R. 1981. Eroding the base of civilization. Journal of Soil and Water Conservation 36 (5), 255-260.

Burkard, M.B., Kostaschuk, R.A. 1997. Patterns and controls of gully growth along the shoreline of lake Huron. Earth Surface Processes and Landforms 22, 901-911. https://doi.org/10.1002/ (SICI)1096-9837(199710)22:10<901:AID-ESP743>3.0.CO;2-O.

Burylo, M., Rey, F., Mathys, N., Dutoit, T. 2012. Plant root traits affecting the resistance of soils to concentrated flow erosion. Earth Surface Processes and Landforms 37, 1463-1470. https:// doi.org/10.1002/esp.3248.

Camacho Valdez, V., Ruiz Luna, A. 2012. Conceptual framework and classification of Ecosystem Services. Biociencias 1 (4), 3-15.

Castillo, V.M., Mosch, W.M., García, C.C., Barbera, G.G., Cano, J.A.N., López-Bermúdez, F. 2007. Effectiveness and geomorphological impacts of check dams for soil erosion control in a semiarid Mediterranean catchment: El Carcavo (Murcia, Spain). Catena 70, 416-427. https://doi.org/10.1016/j.catena.2006.11.009.

Castillo, C., Pérez, R., Gómez, J.A. 2014. A conceptual model of check dam hydraulics for gully control: efficiency, optimal spacing and relation with step-pools. Hydrology and Earth System Sciences 18, 1705-1721. https://doi.org/10.5194/hess-18-1705-2014, 2014.

Castillo, C., Gómez, J.A. 2016. A century of gully erosion research: Urgency, complexity and study approaches. Earth-Science Reviews 160, 300-319. https://doi.org/10.1016/j. earscirev.2016.07.009.

Cisneros, J., Cholaky, C., Cantero Gutiérrez, A., González, J., Reynero, M., Diez, A., Bergesio, L. 2012. Erosión hídrica. Principios y técnicas de manejo. Universidad Nacional de Río Cuarto, Córdoba, Argentina.

Costanza, R. 2008. Ecosystem services: multiple classification systems are needed. Biological Conservation 141, 350-352. https://doi.org/10.1016/j.biocon.2007.12.020.

Cotler, H., López, C.A., Martínez-Trinidad, S. 2011. ¿Cuánto nos cuesta la erosión de los suelos? Aproximación a una valoración económica de la pérdida de suelos agrícolas en México. Investigación Ambiental 3, 31-43.

Coutancier, B. 2004. Restaurer la montagne. Photographies des eaux et forêts du XIXe siècle. Somogy Éditions d'Art, Paris.

Dabny, S.M., Meyer, L.D., Dunn, G.H., Foster, G.R., Alonso, C.V. 1996. Stiff grass hedges. A vegetative alternative for sediment control. Proceedings of the Sixth Federal Interagency Sedimentation Conference vol. 2 (X), 62-69. 
Daniels, R.B., Gilliam, J.W. 1996. Sediment and chemical load reduction by grass and riparian filters. Soil Science Society of America Journal 60 (1), 246-251. https://doi.org/10.2136/ sssaj1996.03615995006000010037x.

De Baets, S., Poesen, J., Gyssels, G., Knapen, A. 2006. Effects of grass roots on the erodibility of topsoils during concentrated flow. Geomorphology 76, 54-67. https://doi.org/10.1016/j. geomorph.2005.10.002.

De Baets, S., Poesen, J., Knapen, A., Galindo Morales, P. 2007. Impact of root architecture, soil characteristics and flow shear stress on the erosion-reducing potential of roots during concentrated flow. Earth Surface Processes and Landforms 32, 1323-1345. https://doi. org/10.1002/esp.1470.

De Baets, S., Poesen, J., Reubens, B., Muys, B., De Baerdemaeker, J., Meersmans, J. 2009. Methodological framework to select plant species for controlling rill and gully erosion: application to a Mediterranean ecosystem. Earth Surface Processes and Landforms 34, 13741392. https://doi.org/ 10.1002/esp.1826.

De Groot, R.S., Wilson, M.A., Boumans, R.M.J. 2002. A typology for the classification, description and valuation of ecosystem functions, goods and services. Ecological Economics 41 (3), 393408. https://doi.org/10.1016/S0921-8009(02)00089-7.

De Vente, J., Poesen, J., Verstraeten, G. 2005. The application of semi-quantitative methods and reservoir sedimentation rates for the prediction of basin sediment yield in Spain. Journal of Hydrology 305, 63-86. https://doi.org/10.1016/S0921-8009(02)00089-7.

Den Biggelaar, C., Lal, R., Wiebe, K., Breneman, V. 2004. The global impact of soil erosion on productivity. 1: Absolute and Relative Erosion-induced Yield Losses. Advances in Agronomy 81, 1-48. https://doi.org/ 10.1016/S0065-2113(03)81001-5.

Desmet, P.J.J., Poesen, J., Govers, G., Vandaele, K. 1999. Importance of slope gradient and contributing area for optimal prediction of the initiation and trajectory of ephemeral gullies. Catena 37 (3-4), 377-392. https://doi.org/10.1016/S0341-8162(99)00027-2.

Desta, L., Adugna, B. 2012. A Field Guide on Gully Prevention and Control. Nile Basin Initiative.

Díaz, S. 2006. Biodiversity regulation of ecosystem services. In: R. Hassan, R. Scholes, N. Ash (Eds.), Ecosystems and hu-human well-being: Current state and trends, Vol. 1. Findings of the Condition and Trends Working Group of the Millennium Ecosystem Assessment. Island Press, Washington, D.C.

Dominati, E., Patterson, M., Mackay, A. 2010. A framework for classifying and quantifying the natural capital and ecosystem services of soils. Ecological Economics 69, 1858-1868. https:// doi.org/10.1016/j.ecolecon.2010.05.002.

Ehrensperger, A., Bach, S., Liniger, H., Portner, B., Ayele, H. 2015. Effectiveness of jatropha barriers as a soil and water conservation technology to rehabilitate gullies in northern Ethiopia. Journal of Soil and Water Conservation 70 (2), 33-38. https://doi.org/10.2489/jswc.70.2.33A.

Ene, G.E., Okogbue, C. O. 2015. Construction and Performance of Geo-engineering Structures for Combating Gully Erosion in South-Eastern Nigeria. Engineering Geology for Society and Territory 2, 857-864. https://doi.org/10.1007/978-3-319-09057-3_147.

Erktan, A., Cécillon, L., Roose, E., Frascaria-Lacoste, N., Rey, F. 2013. Morphological diversity of plant barriers does not increase sediment retention in eroded marly gullies under ecological restoration. Plant Soil 370, 653-669. https://doi.org/10.1007/s11104-013-1738-5.

FAO, 2000. Manual on the Integrated Soil Management and Conservation Practices. FAO, Rome. Ferrer, G.,La Roca,F., Gual, M. 2012. Servicios ecosistémicos: ¿una herramienta para la protección o para la mercantilización de la naturaleza? XIII Jornadas de Economía crítica, 291-294.

Fiener, P., Auerswald, K. 2006. Seasonal variation of grassed waterway effectiveness in reducing runoff and sediment delivery from agricultural watersheds in temperate Europe. Soil \& Tillage Research 87, 48-58. https://doi.org/10.1016/j.still.2005.02.035. 
Frankl, A., Poesen, J., Haile, M., Deckers, J., Nyssen, J. 2013. Quantifying long-term changes in gully networks and volumes in dryland environments: the case of Northern Ethiopia. Geomorphology 201, 254-263. https://doi.org/10.1016/j.geomorph.2013.06.025.

Frankl, A., Deckers, J., Moulaert, L., Van Damme, A., Haile, M., Poesen, J., Nyssen, J. 2014. Integrated solutions for combating gully erosion in areas prone to soil piping: innovations from the drylands of northern Etiopia. Land Degradation and Development 27, 1797-1804. https://doi.org/ 10.1002/ldr.2301.

Gallart, F., Marignani, M., Pérez-Gallego, N., Santi, E., Maccherini, S. 2013. Thirty years of studies on badlands, from physical to vegetational approaches. A succinct review. Catena 106, 4-11. https://doi.org/10.1016/j.catena.2012.02.008.

García Ruíz, J.M., Puigdefábregas, J. 1985. Efectos de la construcción de pequeñas presas en cauces anastomosados del Pirineo Central. Cuadernos de Investigación Geográfica 10, 91 102. http://doi.org/10.18172/cig.946.

Godwin Ezekwesili, E., Celestine Obialo, O. 2015. Construction and Performance of Geoengineering Structures for Combating Gully Erosion in South-Eastern Nigeria. In: G. Lollino, D. Giordan, G.B. Crosta (Eds.), $12^{\text {th }}$ International IAEG Congress Torino (Italy). IAEG. Engineering geology for society and territory. Landslide processes 2, 857-864. https:// doi.org/10.1007/978-3-319-09057-3_147.

Giger, M., Liniger, H., Sauter, C., Schwilch, G. 2015. Economic benefits and costs of sustainable land management technologies: an analysis of WOCAT's global data. Land Degradation and Development 29 (4), 962-974. https://doi.org/10.1002/ldr.2429.

Gómez, B., Banbury, K., Marden, M., Trustrum, N.A., Peacock, D.H., Hoskin, P.J. 2003. Gully erosion and sediment production, Te Weraroa Stream, New Zealand. Water Resources Research 39 (7), 1187. https://doi.org/10.1029/2002WR001342, 2003.

Gómez, J.A., Francia, J.R., Guzmán, G., Vanwalleghem, T., Durán Zuazo, V.H., Castillo, C., Aranda, M., Cárceles, B., Moreno, A., Torrent, L., Barrón, V. 2017. Lateral transfer of organic carbon and phosphorus by water erosion at hillslope scale in southern Spain olive orchards. Vadose Zone Journal 16 (12). https://doi.org/10.2136/vzj2017.02.0047.

Gómez Gutiérrez, A., Schnabel, S., Lavado Contador, F. 2011. Procesos, factores y consecuencias de la erosión por cárcavas. Trabajos desarrollados en la Península Ibérica. Boletín de la Asociación de Geógrafos Españoles 55, 59-80.

Haile, G.W., Fetene, M. 2012. Assesment of soil erosion hazard in Kilie catchment, East Shoa, Ethiopia. Land Degradation and Development 23, 293-306. https://doi.org/10.1002/ldr.1082.

Hansen, W.F., Law, D.L. 2008. Gully control on the Sumter National Forest in S.C. Proceedings of the 2008 South Carolina Water Resources Conference.

Haregeweyn, N., Poesen, J., Nyssen, J., de Wit, J., Haile, M., Govers, G., Deckers, S. 2003. Reservoirs in Tigray (Northern Ethiopia): Characteristics and sediment deposition problems. Land Degradation and Development 17 (2), 211-230. https://doi.org/10.1002/ldr.698.

Haregeweyn, N., Poesen, J., Nyssen, J., Govers, G., Verstraeten, G., de Vente, J., Deckers, J., Moeyersons, J., Haile, M, 2008. Sediment yield variability in Northern Ethiopia: A quantitative analysis of its controlling factors. Catena 75, 65-76. https://doi.org/10.1016/j.catena.2008.04.011.

Haregeweyn, N., Tsunekawa, A., Nyssen, J., Poesen, J., Tsubo, M., Meshesha, DT., Schütt, B., Adgo, E., Tegegne, F. 2015. Soil erosion and conservation in Ethiopia: A review. Progress in Physical Geography 39 (6), 750-774. https://doi.org/10.1177/0309133315598725.

Heede, B.H., Mufich, J.G. 1974. Field and computer procedures for gully control by check dams. Journal of Environmental Management 2, 1-49.

Heede, B.H. 1977. A case study of a watershed rehabilitation project: Alkali Creek Colorado. Res. Pap. RM-189. Fort Collins, CO: U.S. Department of Agriculture, Forest Service, Rocky Mountain Forest and Range Experiment Station. 
Heede, B.H. 1982. Gully control: determining treatment priorities for gullies in a network. Environmental Management 6 (5), 441-451. https://doi.org/10.1007/BF01871892.

Hein, L. 2007. Assessing the costs of land degradation: a case study for the Puentes catchments, Southeast Spain. Land Degradation and Development 18, 631-642. https://doi.org/10.1002/ ldr.802.

Ionita, I. 2011. The human impact on soil erosion and gullying in the Moldavian Plateau, Romania. Landform Analysis 17, 71-73.

Ionita, I., Fullen, M.A., Zgłobicki, W., Poesen, J. 2015. Gully erosion as a natural and humaninduced hazard. Natural Hazards 79, S1-S5. https://doi.org/10.1007/s11069-015-1935-z.

Issaka, S., Ashraf, M.A. 2017. Impact of soil erosion and degradation on water quality: A review. Geology, Ecology, and Landscapes 1 (1), 1-11. https://doi.org/10.1080/24749508.2017.130 1053.

Kennedy, A., Gillen, J., Keetch, B., Creaser, C., Communit, M. 2001. Gully erosion control at Kantju Gorge, Uluru-Kata Tjuta National Park, central Australia. Ecological management \& Restoration 2 (1), 17-27. https://doi.org/10.1046/j.1442-8903.2001.00064.x.

Kirkby, M.J., Bracken, L.J. 2009. Gully processes and gully dynamics. Earth Surface Processes and Landforms 34 (14), 1841-1851. https://doi.org/10.1002/esp.1866.

Knight, K.W., Schultz, R.C., Mabry, C.M., Isenhart, T.M. 2010. Ability of remnant riparian forests, with and without grass filters, to buffer concentrated surface runoff. Journal of the American Water Resources Association 46 (2), 311-322. https://doi.org/10.1111/j.17521688.2010.00422.x.

Lal, R. 1992. Restoring land degraded by gully erosion in the tropics. Advances in Soil Science 17, 123-152. https://doi.org/10.1007/978-1-4612-2820-2_5.

Leguédois, S., Ellis, T.W., Hairsine, P.B., Tongway, D.J. 2008. Sediment trapping by a tree belt: processes and consequences for sediment delivery. Hydrological Processes 22, 3523-3534. https://doi.org/10.1002/hyp.6957.

Li, H., Cruse, R.M., Bingner, R.L., Gesch, K.R., Zhang, X. 2016. Evaluating ephemeral gully erosion impact on Zea mays L. yield and economics using AnnAGNPS. Soil and Tillage Research 155, 157-165. https://doi.org/10.1016/j.still.2015.07.018

Liggitt, B., Fincham, R.J. 1989. Gully erosion: the neglected dimension in soil erosion research. South African Journal of Science 85 (1), 18-20.

Luck, G.W., Harrington, R., Harrison, P.A., Kremen, C., Berry, P.M., Bugter, R., Dawson, T.P., de Bello, F., Diaz, S., Feld, C.K., Haslett, J.R., Hering, D., Kontogianni, A., Lavorel, S., Rounsevell, M., Samways, M.J., Sandin, L., Settele, J., Sykes, M.T., van den Hove, S., Vandewalle, M., Zobel, M. 2009. Quantifying the Contribution of Organisms to the Provision of Ecosystem Services. Bioscience 59 (3), 223-235. https://doi.org/10.1525/ bio.2009.59.3.7.

MA [Millennium Ecosystem Assessment] 2005. Ecosystems and Human Well-being: Synthesis. Island Press, Washington, DC.

Mansour Jahantigh, M., Pessarakli, M. 2011. Causes and Effects of Gully Erosion on Agricultural Lands and the Environment. Communications in Soil Science and Plant Analysis 42 (18), 2250-2255. https://doi.org/10.1080/00103624.2011.602456

Martín-Moreno, C., Fidalgo Hijano, C., Martín Duque, J.F., González-Martín, J.A., Zapico, I., Laronne, J. 2014. The Ribagorda sand gully (east-central Spain): Sediment yield and human-induced origin. Geomorphology 224, 122-138. https://doi.org/10.1016/j. geomorph.2014.07.013.

Martineli Costa, F., Prado Bacellar, L.A. 2007. Analysis of the influence of gully erosion in the flow pattern of catchment streams, Southeastern Brazil. Catena 69, 230-238. https://doi. org/10.1016/j.catena.2006.05.007. 
Martínez-Casasnovas, J.A. Antón-Fernández, C., Ramos, M.C., 2003. Sediment production in large gullies of the Mediterranean area (NE Spain) from high-resolution digital elevation models and geographical information systems analysis. Earth Surface Processes and Landforms 28 (5), 443-456. https://doi.org/10.1002/esp.451.

Martínez Castroviejo, R., Inbar, M., Gómez villar, A., García Ruíz, J.M. 1990. Cambios en el cauce aguas debajo de una presa de retención de sedimentos. I Reunión Nacional de Geomorfología, Teruel, 457-468.

Marzolff, I., Poesen, J., Ries, J.B. 2011. Short to medium-term gully development: human activity and gully erosion variability in selected Spanish gully catchments. Landform Analysis 17, 111-116

Mekdaschi Studer, R., Liniger, H. 2007. Use of WOCAT tools and network to prepare for SLM adaptation to climate change - identification of conservation technologies suitable for climate change. Available at: https://www.wocat.net/fileadmin/user_upload/documents/Articles/ WOCATAdapt_CC.pdf.

Mekonnen, M., Keesstra, S.D., Stroosnijder,L., Baartman, J.E, Maroulis, J. 2015. Soil conservation through sediment trapping: a review. Land Degradation and Development 26, 544-556. https://doi.org/10.1002/ldr.2308.

Meyer, L.D., Dabney, S.M., Harmon, W.C. 1995. Sediment-trapping effectiveness of stiff-grass hedges. Transactions of the ASAE 38 (3), 809-815. https://doi.org/10.13031/2013.27895.

Milton, L. E. 1971. A review of gully erosion and its control. Soil Conservation Authority, Victoria.

Moges, A., Holden, N.M. 2008. Estimating the rate and consequences of gully development, a case study of umbulo catchment in Southern Ethiopia. Land Degradation and Development 19, 574-586. https://doi.org/10.1002/ldr.871.

Mongil, J., Navarro, J., Díaz, V. 2015. Esquema ecológico aplicado a una restauración forestal en cárcavas de la Sierra de Ávila (centro de España). Madera y Bosques 21 (1), 11-19. https:// doi.org/10.21829/myb.2015.211429.

Mora Jordano, J., Lora González, A., Castillo Rodríguez, C., Muñoz Macías, F., Rojo Aranda, M., Gómez Calero, J. 2013. Técnicas de control de cárcavas mediante el uso de vegetación forestal y diques de retención en explotaciones agrícolas. El caso de la finca "La Veguilla". $6^{\circ}$ Congreso Forestal español, pp. 2-14.

Morgan, R.P.C. 1995. Soil Erosion and Conservation. Second Edition. Longman, Essex.

Morris, B.T., Johnson, D.C. 1943. Hydraulic Design of Drop Structures for Gully-Control. Transactions, American Society of Civil Engineers 108, 887-940.

Nadal Romero, E., Regüés, D. 2010. Geomorphological dynamics of subhumid mountain badland areas - weathering, hydrological and suspended sediment transport processes: A case study in the Aragua's catchment (Central Pyrenees) and implications for altered hydroclimatic regimes. Progress in Physical Geography 34 (2), 123-150. https://doi. org/10.1177/0309133309356624.

Nadal Romero, E., Torri, D., Yair, A. 2013. Updating the badlands experience. Catena 106, 1-3. https://doi.org/10.1016/j.catena.2012.07.009.

Nearing, M., Pruski, F.F., O’Neal, M.R. 2004. Expected climate change impacts on soil erosion rates: A review. Journal of Soil and Water Conservation, 59 (1), 43-50.

Nyssen, J., Veyret-Picot, M., Poesen, J. 2004. The effectiveness of loose rock check dams for gully control in Tigray, northern Ethiopia. Soil Use and Management 20 (1), 55-64. https://doi. org/10.1111/j.1475-2743.2004.tb00337.x.

Nyssen, J., Poesen, J., Haile, M. 2009. Effects of land use and land cover on sheet and rill erosion rates in the Tigray highlands, Ethiopia. Zeitschrift für Geomorphologie 53, 171-197. https:// doi.org/10.1127/0372-8854/2009/0053-0171.

Obi Lawrence, E. 2017. Application of retaining wall in the control of flooding and gully erosion. American Journal of Engineering Research (AJER) 6 (9), 203-206. 
Ohde, N.R. 2011. Ephemeral gullies and ecosystem services: Social and biophysical factors. Master's thesis, Iowa State University.

Okagbue, C.O., Uma, K.O. 1987. Performance of gully erosion control measures in southeastern Nigeria. IAHS Publications 167, 163-172.

Ollobarren, P., Capra, A., Gelsomino, A., La Spada, C. 2016. Effects of ephemeral gully erosion on soil degradation in a cultivated area in Sicily (Italy). Catena 145, 334-345. https://doi. org/10.1016/j.catena.2016.06.031.

Palacio-Prieto, J.L., López-Blanco, J. 1994. Using video imagery for gully erosion evaluation. Zeitschrift für Geomorphologie 38 (1), 33-43.

Panagos, P., Standardi, G., Borrelli, P., Lugato, E., Montanarella, L., Bosello, F. 2018. Cost of agricultural productivity loss due to soil erosion in the European Union: From direct cost evaluation approaches to the use of macroeconomic models. Land Degradation and Development 18, 1-14. https://doi.org/10.1002/ldr.2879.

Pathak,P., Wan,S.P.,Sudi, R. 2005. Gully Control in SAT Watershed. Global Theme in Agroecosystem. Report No. 15. International Crop Research Institute for Semiarid Tropic, 28 pp.

Poesen, J., Vandaele, K., van Wesemael, B. 1996. Contribution of gully erosion to sediment production in cultivated lands and rangelands. IAHS Publications 236, 251-266.

Poesen, J., Hooke, J.M. 1997. Erosion, flooding and channel management in Mediterranean environments of southern Europe. Progress in Physical Geography 21 (2), 157-199. https:// doi.org /10.1177/030913339702100201.

Poesen, J., Vandekerckhove, L., Nachtergaele, J., Oostwoud Wijdenes, D., Verstraeten, G., van Wesemael, B. 2002. Gully erosion in dryland environments. In: L.J. Bull, M.J. Kirkby (Eds.), Dryland Rivers: Hydrology and Geomorphology of Semi-Arid Channels. Wiley, Chichester, pp. 229-262.

Poesen, J., Valentin, C. (Eds.). 2003. Gully erosion and Global Change. Catena 50 (2-4), 87-564.

Poesen, J., Nachtergaele, J., Verstraeten, G., Valentin, C. 2003. Gully erosion and environmental change: importance and research needs. Catena 50 (2-4), 91-133. https://doi.org/10.1016/ S0341-8162(02)00143-1.

Poesen, J., Vanwalleghem, T., de Vente, J., Knapen, A., Verstraeten, G., Martínez-Casasnovas, J.A. 2006. Gully erosion in Europe. In: J. Boardman, J. Poesen (Eds), Soil erosion in Europe. Wiley, Chichester, pp 515-536.

Poesen, J. 2011. Challenges in gully erosion research. Landform Analysis 17, 5-9.

Poesen, J. 2018. Soil erosion in the Anthropocene: Research needs. Earth Surface Processes and Landforms 43, 64-84. https://doi.org/10.1002/esp.4250.

Polyakov, V.O., Nichols, M.H., McClaran, M.P., Nearing, M.A. 2014. Effect of check dams on runoff, sediment yield, and retention on small semiarid watersheds. Journal of Soil and Water Conservation 69, 414-421. https://doi.org/10.2489/jswc.69.5.414.

Potschin, M.B., Haines-Young, R.H. 2011. Ecosystem services: Exploring a geographical perspective. Progress in Physical Geography 35 (5), 575-594. https://doi. org/10.1177/0309133311423172.

Quiñonero-Rubio, J.M., Nadeu, E., Boix-Fayos, C., de Vente, J. 2016. Evaluation of the effectiveness of forest restoration and check-dams to reduce catchment sediment yield. Land Degradation and Development 27, 1018-1031. https://doi.org/10.1002/ldr.2331.

Rey, F. 2003. Influence of vegetation distribution on sediment yield in forested marly gullies. Catena 50, 549-562. https://doi.org/10.1016/S0341-8162(02)00121-2.

Richet, J.B., Ouvry, J.F., Saunier, M. 2016. The role of vegetative barriers such as fascines and dense shrub hedges in catchment management to reduce runoff and erosion effects: Experimental evidence of efficiency, and conditions of use. Ecological Engineering 103, 455-469. https://doi.org/10.1016/j.ecoleng.2016.08.008. 
Ries, J.B., Marzolff, I. 2003. Monitoring of gully erosion in the Central Ebro Basin by large-scale aerial photography taken from a remotely controlled blimp. Catena 50, 309-328. https://doi. org/10.1016/S0341-8162(02)00133-9.

Ritchie, J.C., Kemper, W.D., Englert, J.M. 1997. Narrow stiff grass hedges for erosion control. IAHS Publications 245, 195-203.

Romero Díaz, A., Martínez Lloris, M., Alonso Sarria, F., Belmonte Serrato, F., Marín Sanleandro, P., Ortiz Silla, R., Rodriguez Estrella, T., Sánchez Toribio, M.I. 2007. Los diques de corrección hidrológica. Cuenca del río Quipar (Sureste de España). Editum. Universidad de Murcia, Murcia, $271 \mathrm{pp}$.

Romero Díaz, A., Martínez Hernández, C., Belmonte Serrato, F. 2016. Procesos de erosión en áreas abandonadas de la Región de Murcia. In: A. Romero Díaz (Coord.), Abandono de cultivos en la Región de Murcia. Consecuencias ecogeomorfológicas. Editum, Universidad de Murcia, Murcia, 85-110.

Sagarpa. 2009. Control de Cárcavas. Secretaria de Agricultura, Ganadería, Desarrollo Rural, Pesca y Alimentación, México.

Santos Telles, T. Guimarães, M.F., Falci Dechen, S.C. 2011. The costs of soil erosion. Revista Brasileira de Ciência do Solo 35 (2), 287-298. https://doi.org/10.1590/S010006832011000200001.

Sanz, M.J., de Vente, J., Chotte, J.L., Bernoux, M., Kust, G., Ruiz, I., Almagro, M., Alloza, J.A., Vallejo, R., Castillo, V., Hebel, A., Akhtar-Schuster, M. 2017. Sustainable land management contribution to successful land-based climate change adaptation and mitigation. A Report of the Science-Policy Interface. United Nations Convention to Combat Desertification (UNCCD). Bonn, Germany.

Schmiedel, U., Kruspe, M., Kayser, L. Oettlé, N. 2016. The ecological and financial impact of soil erosion and its control - a case study from the semiarid Northern Cape Province, South Africa. Land Degradation \& Development 28, 74-82. https://doi.org/10.1002/ ldr.2513.

Schouten, C.J., Rang, M.C. 1984. Measurement of gully erosion and the effects of soil conservation techniques in Puketurua experimental Basin (New Zealand). Zeitschrift fur Geomorphologie N.F. Supplement band 49, 151-164.

Shellberg, J.G., Brooks, A.P., Rose, C.W. 2013. Sediment production and yield from an alluvial gully in northern Queensland, Australia. Earth Surface Processes and Landforms 38, 17651779. https://doi.org/10.1002/esp.3414.

Sheng, J., Liao, A. 1997. Erosion control in South China. Catena 29, 211-221. https://doi. org/10.1016/S0341-8162(96)00057-4.

Sherard, J.L., Ryker, N.L., Decker, R.S. 1972. Piping in earth dams of dispersive clay. Proceedings of the Special Conference on the Performance of Earth and Earth Supported Structures. ASCE, pp. 150-161.

Sillmann, J., Kharin, V.V., Zwiers, F.W., Zhang, X., Bronaugh, D. 2013. Climate extremes indices in the CMIP5 multimodel ensemble: Part 2. Future climate projections. Journal of Geophysical Research: Atmospheres 118, 2473-2493. https://doi.org/10.1002/jgrd.50188.

Soil Conservation Society of America (now Soil and Water Conservation Society). 1982. Resource conservation glossary. 3rd ed. Soil Conserv. Soc. Am., Ankeny, IA.

Stokes, A., Atger, C., Glyn Bengough, A., Fourcaud, T., Sidle, R.C. 2009. Desirable plant root traits for protecting natural and engineered slopes against landslides. Plant and Soil 324, 1-30. https://doi.org/10.1007/s11104-009-0159-y.

Stokes, A., Sotir, R., Chen, W., Ghestem, M. 2010. Soil bio- and ecoengineering in China: past experience and future priorities. Ecological Engineering 36, 247-257. https://doi. org/10.1016/j.ecoleng.2009.07.008. 
Styzcen, M.E., Morgan, R.P.C. 1995. Engineering properties of vegetation. In: R.P.C Morgan, R.J. Rickson (Eds), Slope Stabilization and Erosion Control: A Bioengineering Approach. E \& FN SPON, London, pp. 5-58.

Sun, Y., Solomon, S., Dai, A., Portmann, R.W. 2007. How often will it rain? Journal of Climate 20, 4801-4818. https://doi.org/10.1175/JCLI4263.1.

Thornes, J.B. 1990. Vegetation and Erosion-Processes and Environments. John Wiley \& Sons, Chichester.

Toy, T.J., Foster, G.R., Renard, K.G. 2002. Soil Erosion: Processes, Prediction, Measurement, and Control. John Wiley and Sons, Inc., New York.

Valentin, C., Poesen, J., Li, Y. 2005. Gully erosion: Impacts, factors and control. Catena 63, 132153. https://doi.org/10.1016/j.catena.2005.06.001.

Vandekerckhove, L., Poesen, J., Oostwoud, D.J., de Figueiredo, T. 2000. Thresholds for gully initiation and sedimentation in Mediterranean Europe. Earth Surface Processes and Landforms 25 (11), 1201-1220. https://doi.org/10.1002/1096-9837(200010)25:11<1201:AIDESP131>3.0.CO;2-L.

Vandekerckhove, L., Poesen, J., Wijdenes, D.O., Gyssels, G. 2001. Short-term bank gully retreat rates in Mediterranean environments. Catena 44, 133-161. https://doi.org/10.1016/S03418162(00)00152-1.

Vanmaercke, M., Poesen, J., Van Mele, B., Demuzere, M., Bruynseels, A., Golosov, V., Rodrigues Bezerra, J.F., Bolysov, S., Dvinskih, A., Frankl, A., Fuseina, Y., Teixeira Guerra, A.J., Haregeweyn, N., Ionita, I., Makanzu Imwangana, F., Moeyersons, J., Moshe, I., Nazari Samani, A., Niacsui, L., Nyssen, J., Otsuki, Y., Radoane, M., Rysin, I., Ryzhovr,YV., Yermolaev, O. 2016. Earth-Science Reviews 154, 336-355. https://doi.org/10.1016/j.earscirev.2016.01.009.

Weinhold, M. 2007. The Alkali Creek Story: 40 years of gully control. Proceedings of the Forest Service National Earth Sciences. Conference, San Diego, CA, 18-22 October 2004, PNWGTR-689, $271 \mathrm{pp}$.

WOCAT, 2016. World overview of conservation approaches and technologies questionnaire on sustainable land management (SLM). Consult WOCAT at: www.wocat.net.

Yitbarek, T.W., Belliethathan, S., Stringer, I.C. 2012. The onsite cost of gully erosion and costbenefit of gully rehabilitation: a case study in Ethiopia. Land Degradation and Development 23, 157-166. https://doi.org/10.1002/ldr.1065.

Yuan, Y.P., Bingner, R.L., Locke, M.A. 2009. A review of effectiveness of vegetative buffers on sediment trapping in agricultural areas. Ecohydrology 2,321-336. https://doi.org/10.1002/eco.82.

Zhang, G.H., Liu, G.B., Wang, G.L. 2010. Effects of Caragana korshinskii Kom. cover on runoff, sediment yield and nitrogen loss. International Journal of Sediment Research 25, 245-257. https://doi.org/10.1016/S1001-6279(10)60042-X.

Zhang, Y., Hernandez, M., Anson, E., Nearing, M.A., Wei, H., Stone, J.J., Heilman, P. 2012. Modeling climate change effects on runoff and soil erosion in southeastern Arizona rangelands and implications for mitigation with conservation practices, Journal of Soil and Water Conservation 67, 390-405, https://doi.org/10.2489/jswc.67.5.390.

Zhou, X., Helmers, M.J., Al-Kaisi, M., Hanna, H.M. 2009. Cost-effectiveness and cost benefit analysis of conservation management practices for sediment reduction in an Iowa agricultural watershed. Journal of Soil and Water Conservation 64 (5), 314-323. http://doi.org/10.2489/ jswc.64.5.314.

Zgłobicki, W., Poesen, J., Cohen, M., Del Monte, M., García-Ruiz, J.M., Ionita, I., Niacsu, L., Machová, Z., Martín-Duque, J.F., Nadal-Romero, E., Pica, A., Rey, F., Solé-Benet, A., Stankoviansky, M., Stolz, C., Torri, D., Soms, J., Vergari, F. 2017. The Potential of Permanent Gullies in Europe as Geomorphosites. Geoheritage. https://doi.org/10.1007/ s12371-017-0252-1. 